\title{
أبو نواس والفتية
}

Abū Nuwās et les fitya

Abū Nuwās and the Fitya

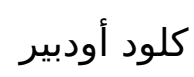

\section{(2) OpenEdition}

Journals

Édition électronique

URL : https://journals.openedition.org/beo/564

DOI : $10.4000 /$ beo. 564

ISBN : 978-2-35159-335-6

ISSN : 2077-4079

\section{Éditeur}

Presses de l'Institut français du Proche-Orient

\section{Édition imprimée}

Date de publication : 1 mai 2012

Pagination : 375-395

ISBN : 978-2-35159-193-2

ISSN : 0253-1623

Référence électronique

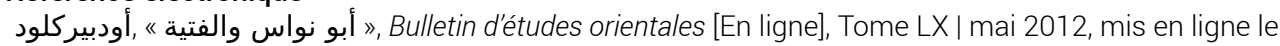
05 juin 2012, consulté le 21 septembre 2021. URL : http://journals.openedition.org/beo/564 ; DOI : https://doi.org/10.4000/beo.564 


\section{أبو نواس والفتية \\ كلود أودبير \\ جامعة بروفانس، إيرمام}

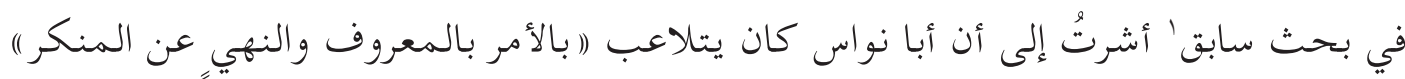

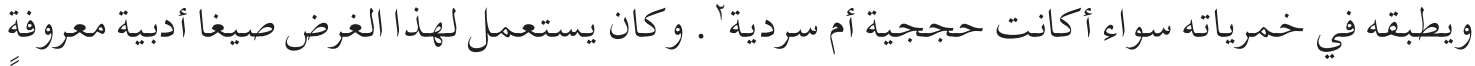

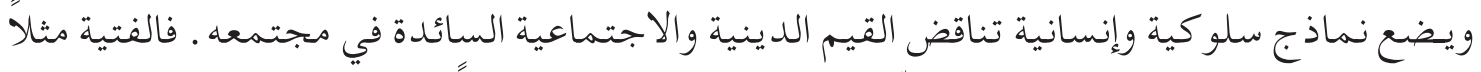

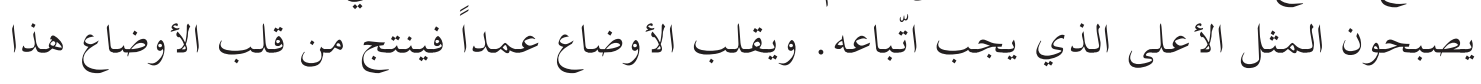

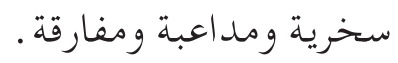

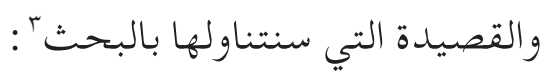

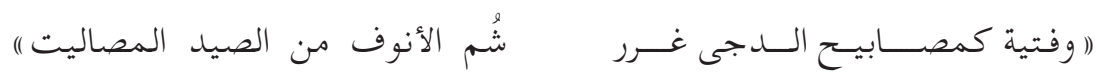

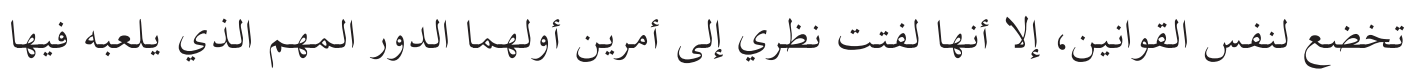

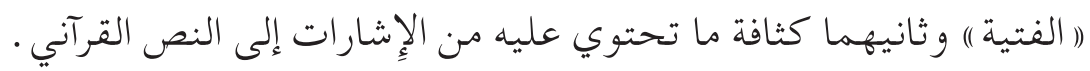

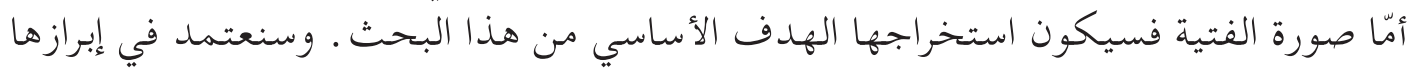

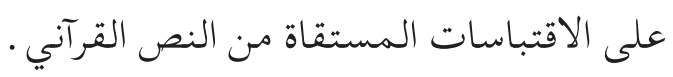

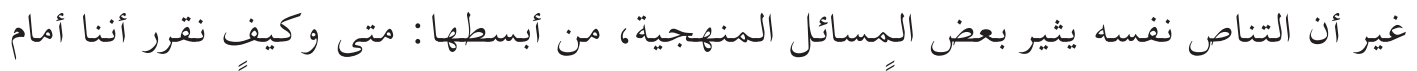

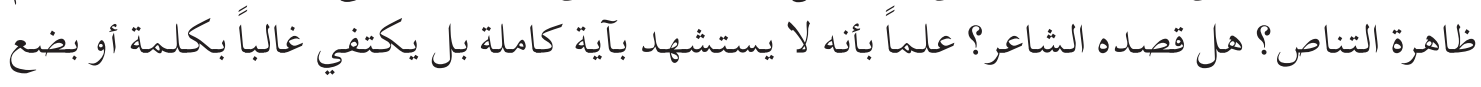
كلمات ؟

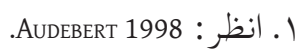

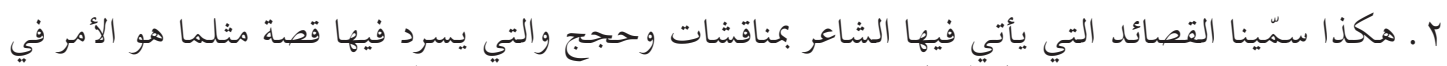

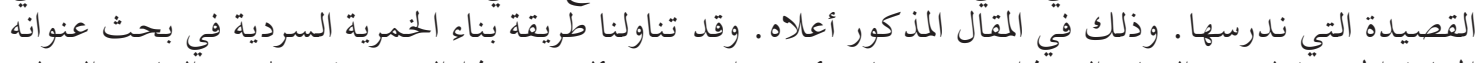

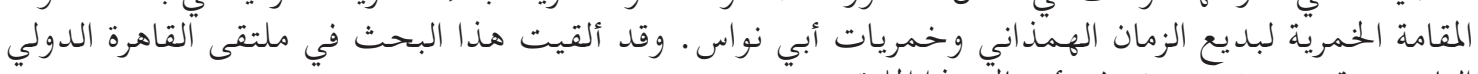

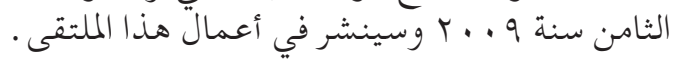

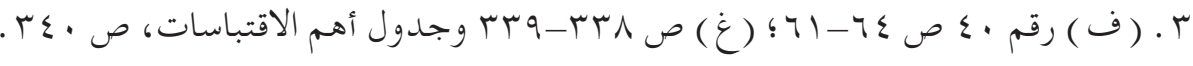


و كيف نختار من بين هذه الإِشارات أنسبها لإفادة المعنى ؟ فِإجابةً لهذه الأسئلة جعلنا القصيدة

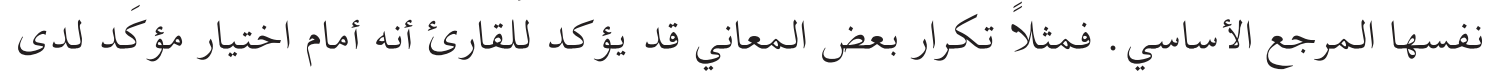

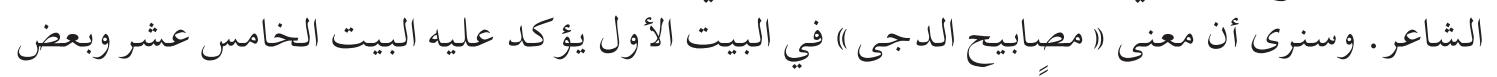

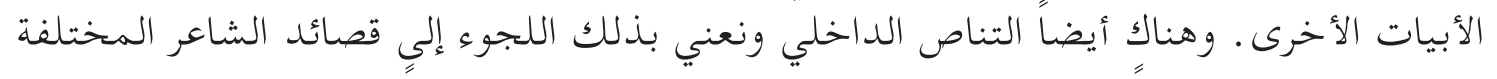

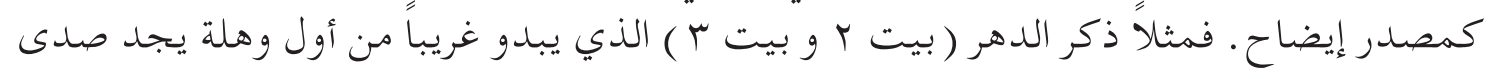

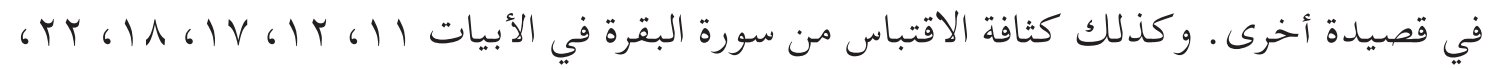

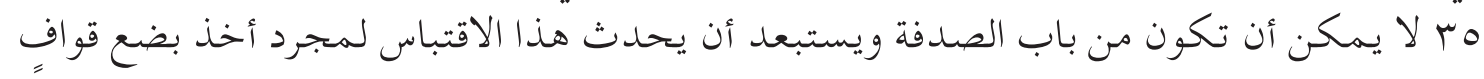

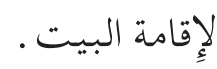

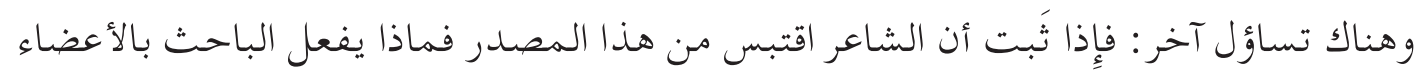

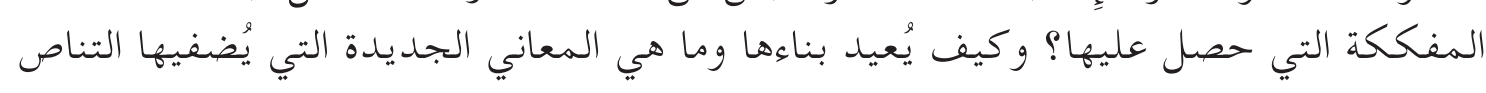
على القصيدة؟ ولقد كرس Montgomery " بحثًا على هذه القصيدة وذكر ما لا يقل عن خمسين آية إلاً أنه لم

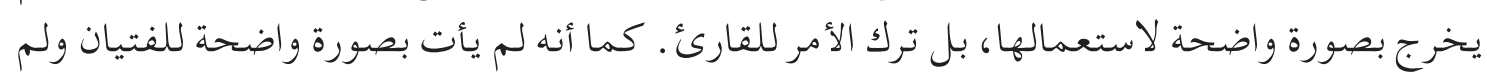
يبرز المعنى العام المتكامل للقصيدة .

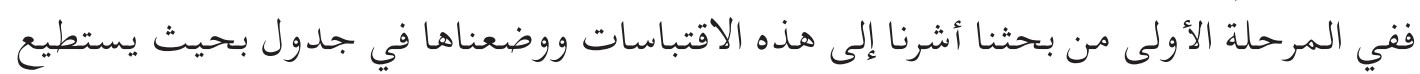

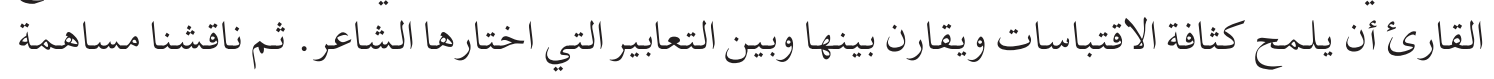

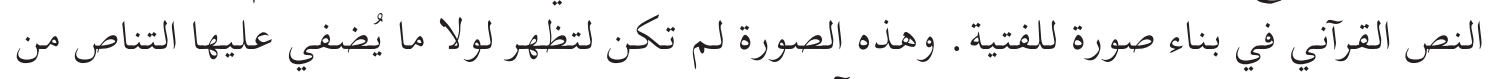

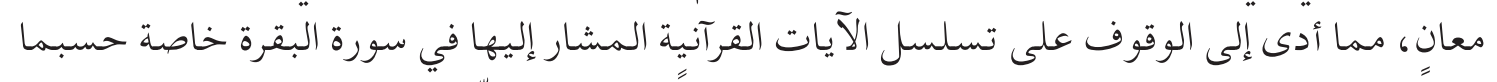

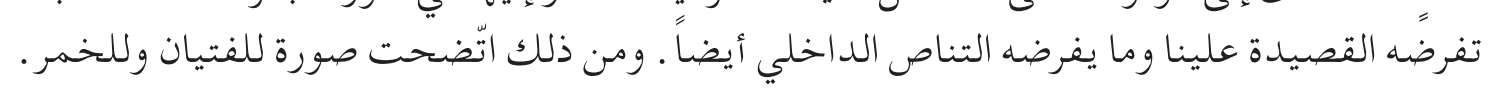

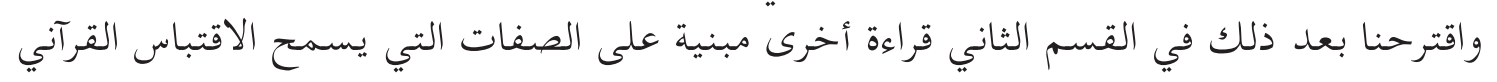
بالاعتماد عليها . سنتّبع في شرحنا ترتيب الأبيات مع الإِشارة إلى مواطن تكرار المعاني والعلاقات بين الأبيات ونحن نهاف إلى استخراج صورة للفتية كما أسلفنا القول .

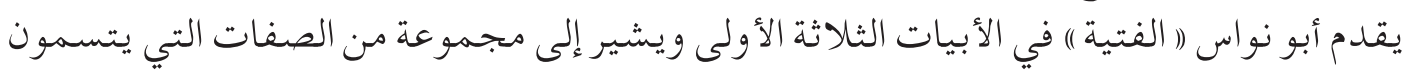

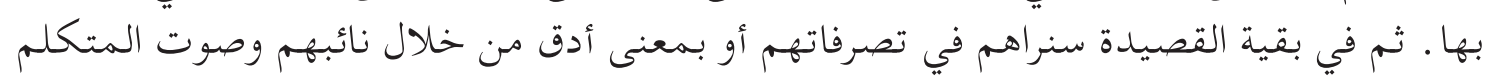
عنهم أي الراوي.

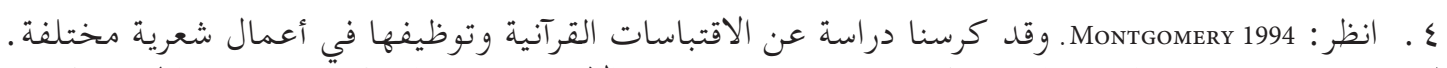

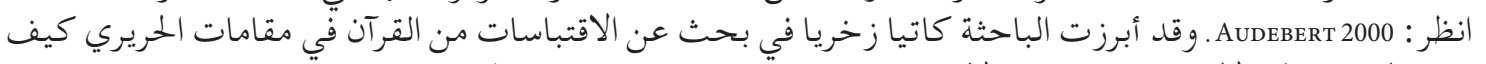

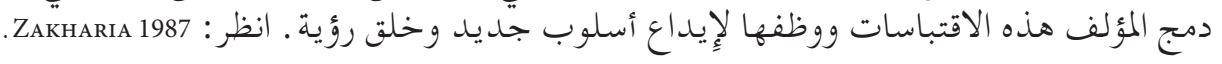




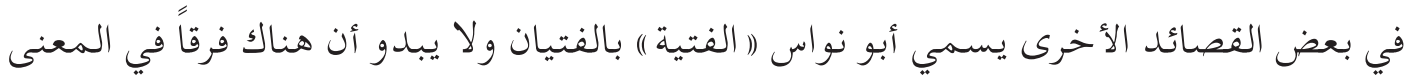

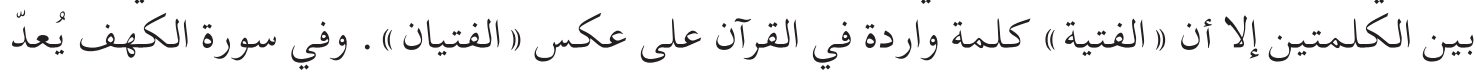

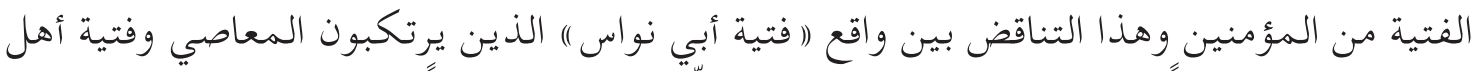

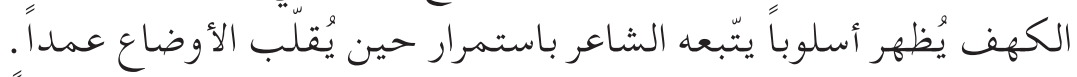

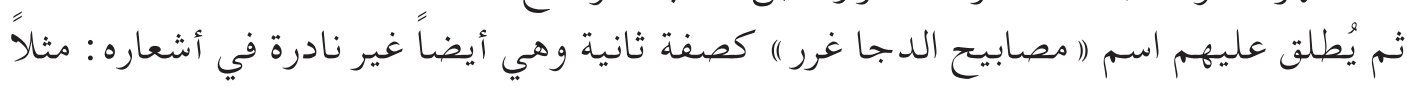

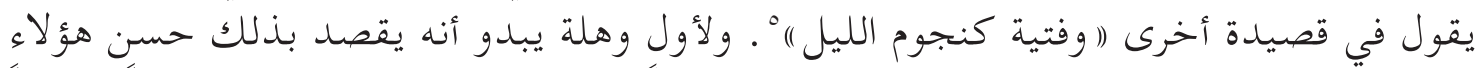

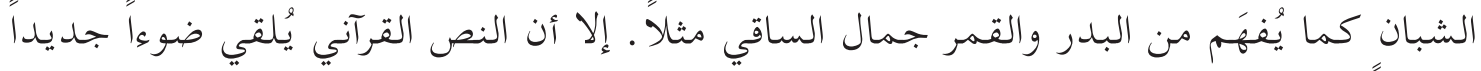

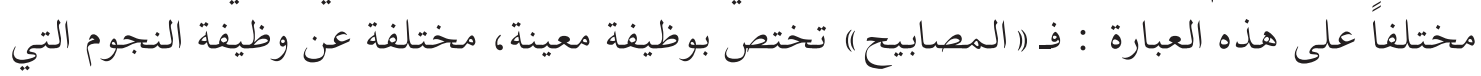

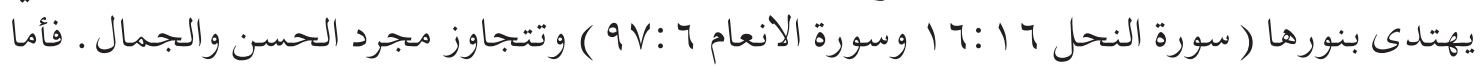

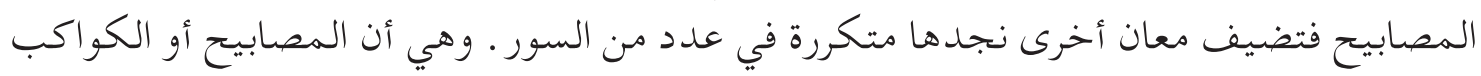

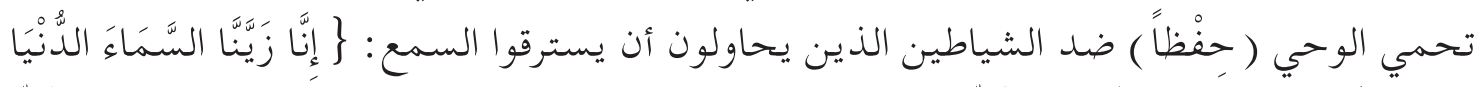

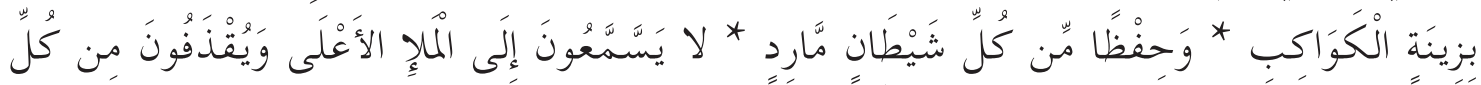

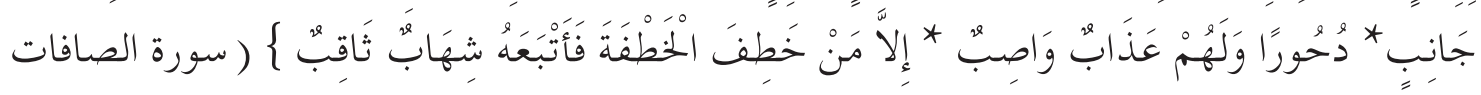
. (1. - T: rV

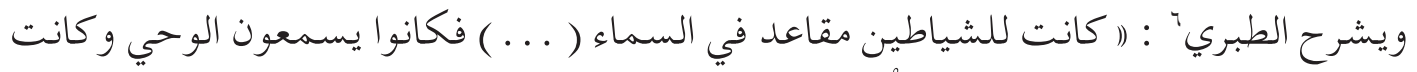

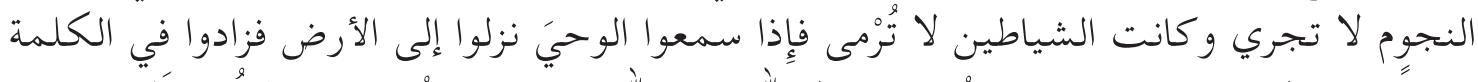

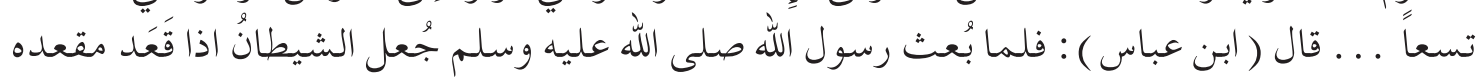
جاء شهاب فلم يخطه حتى يحرقه ) . .

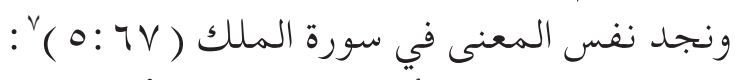

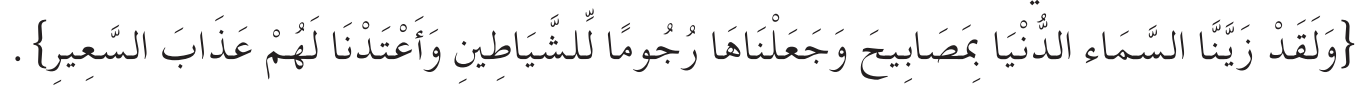

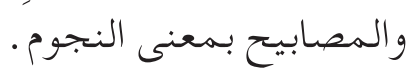

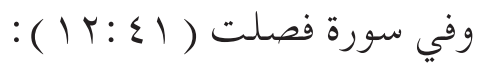

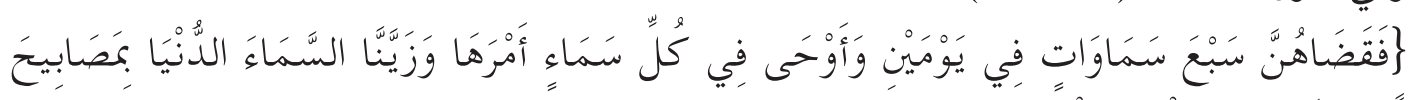

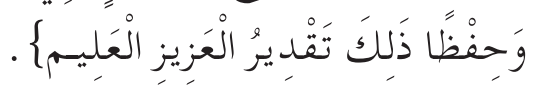

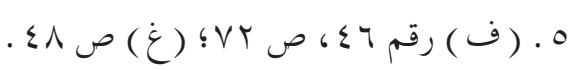

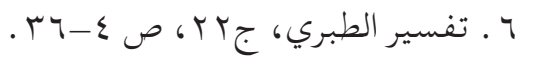

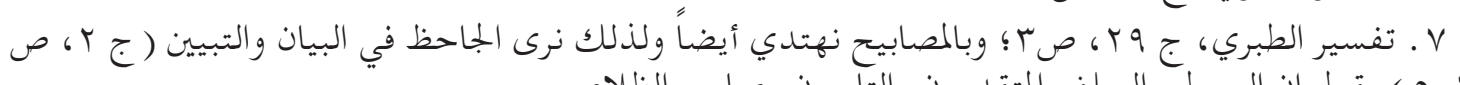

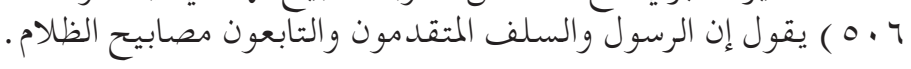




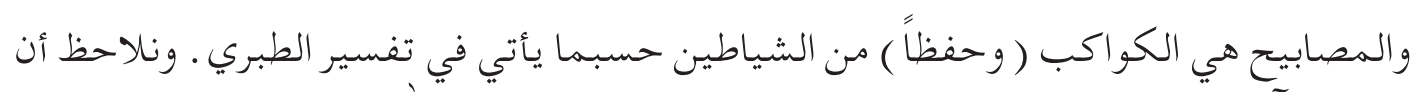

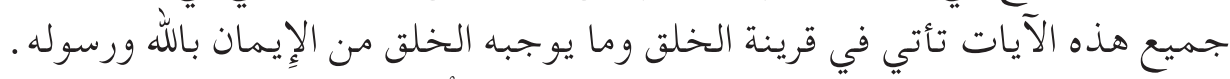

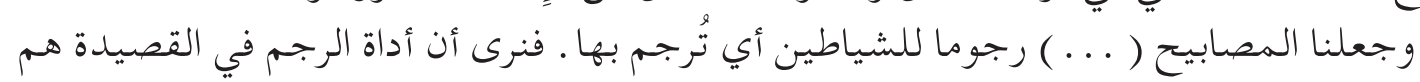

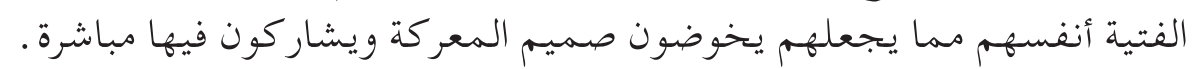

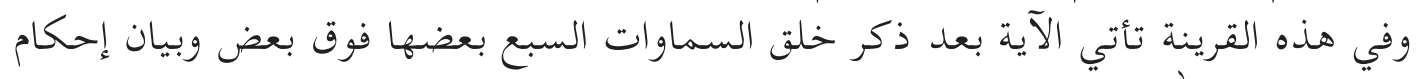
الخلق كَآية لقدرة الله.

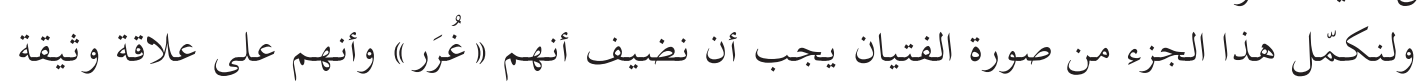

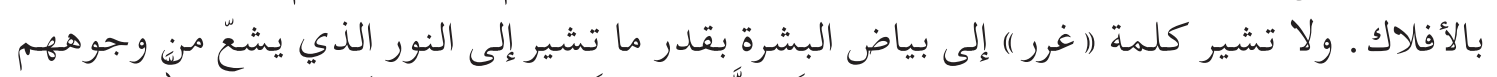

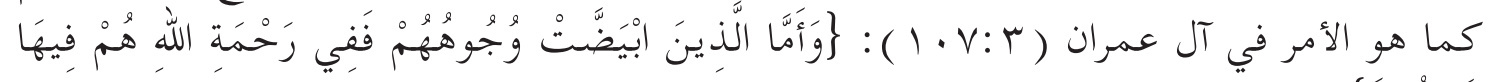

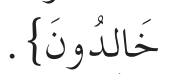
أمّا الأفلاك فترد مرتين في القصيدة ( في البيت الثالث : (ا أفلاك السعود ))؛ وفي البيت السابع

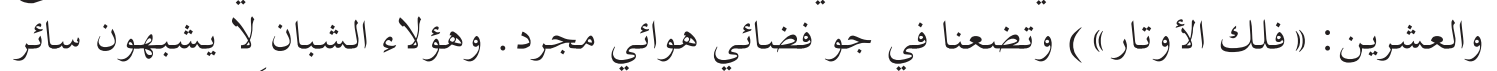

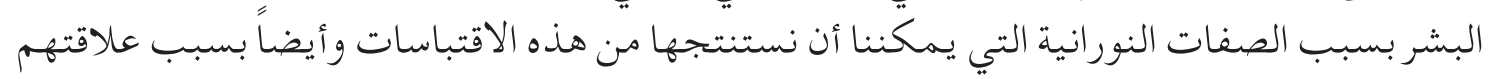

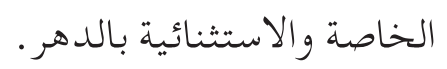

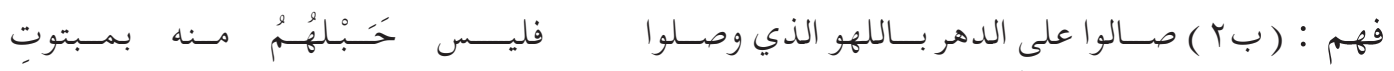

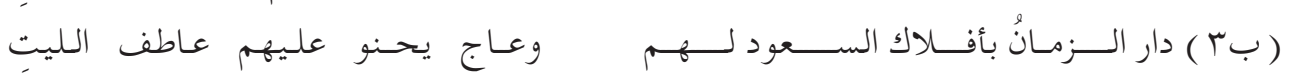

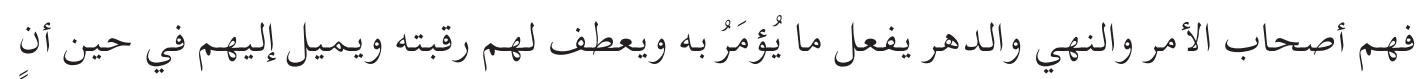

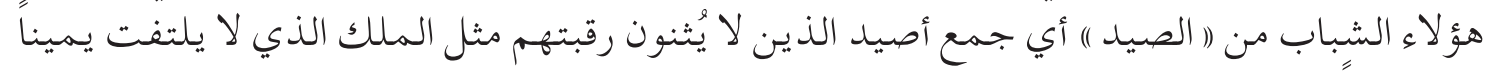

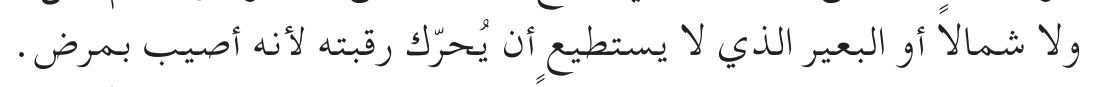

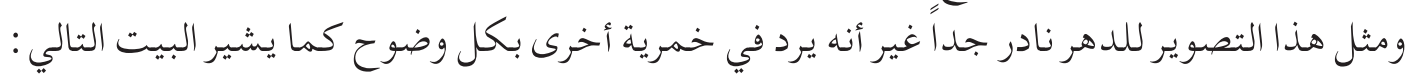

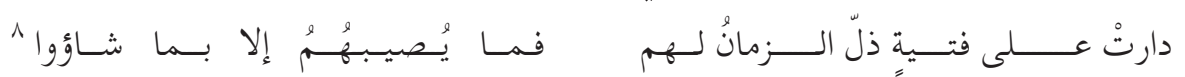
ولا يد ع هذا البيت مجالاً للشك في أن خضوع الدهر لهم هو المعنى المقصود د. وخضوع الدهو الدهر

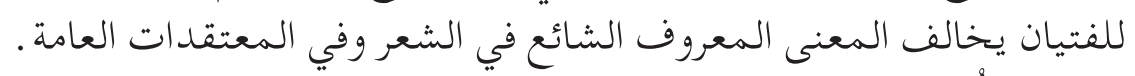

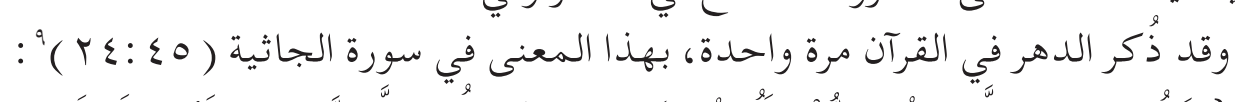

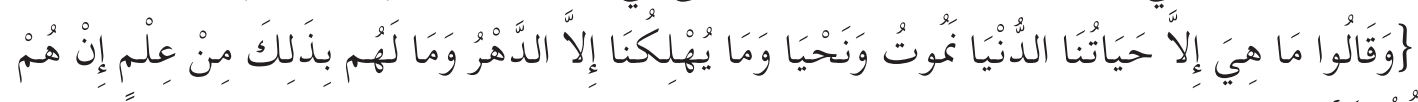
\{

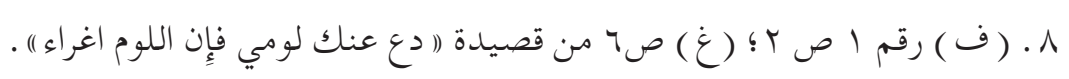

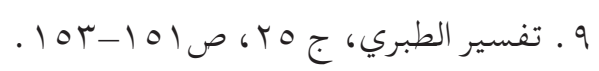


ونزلت الآية رداً لمـن رفض الإِيمان بالبعث بعد الممات ـ و ويعلق الطبري قائلاً إن في حديث من

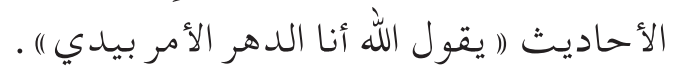

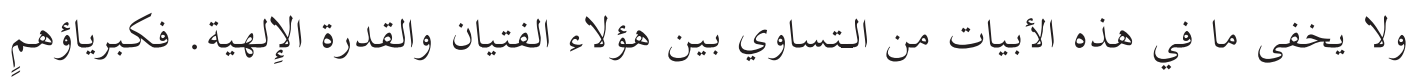

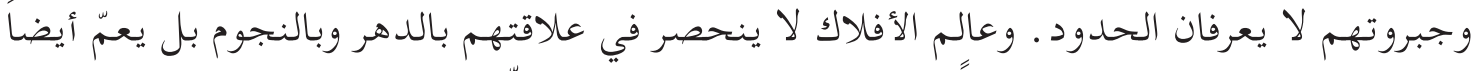

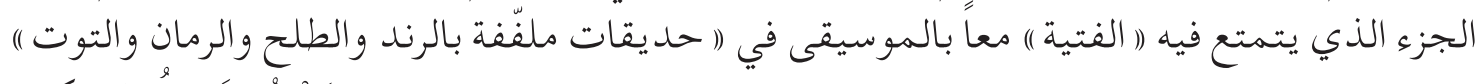

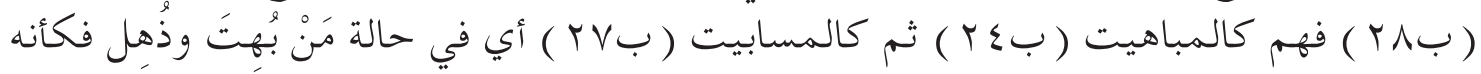

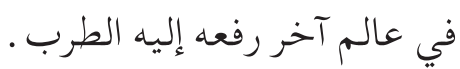

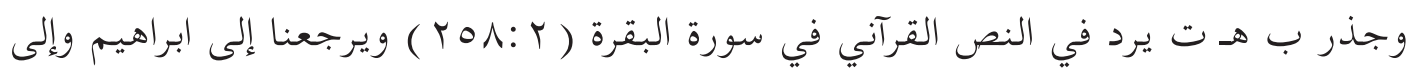

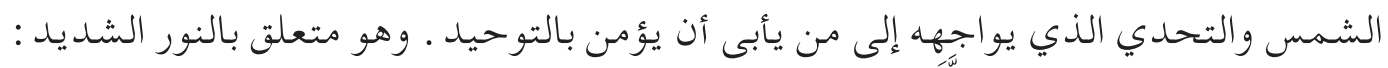

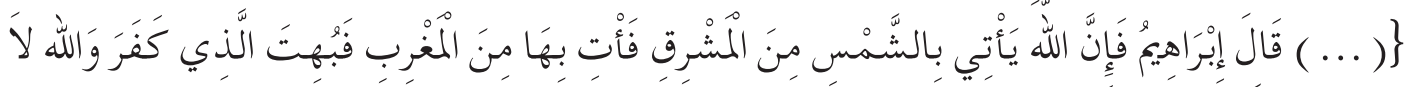

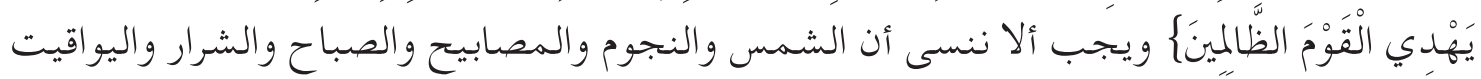

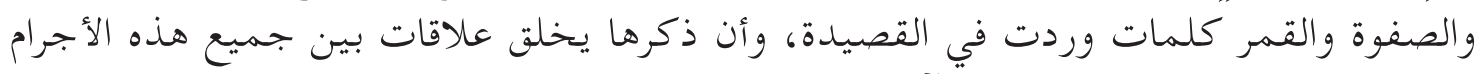

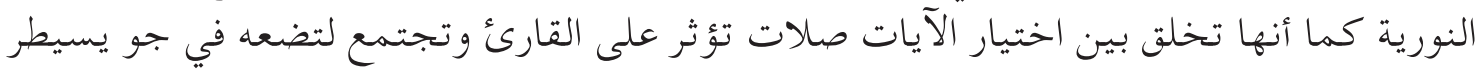

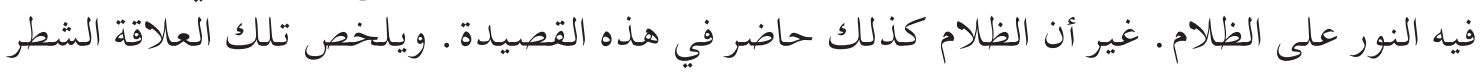

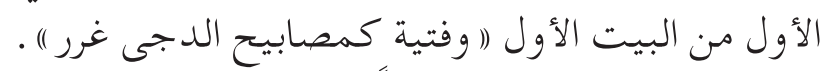

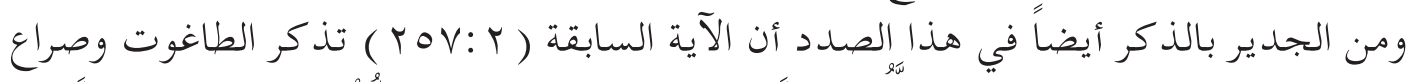

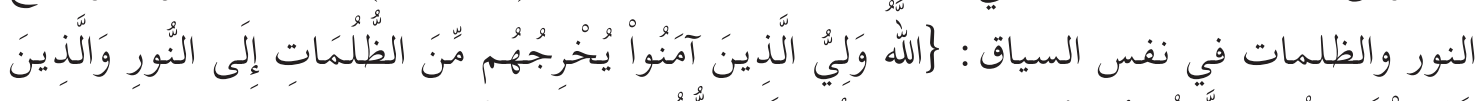

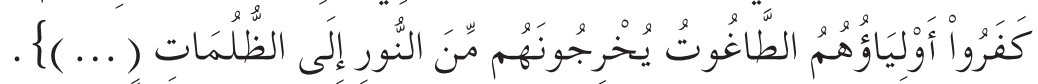

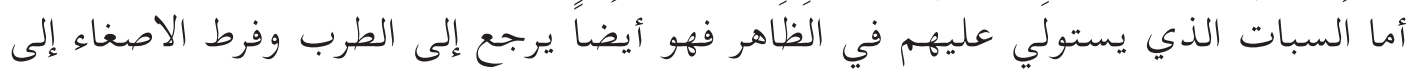

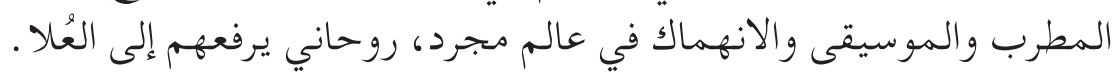

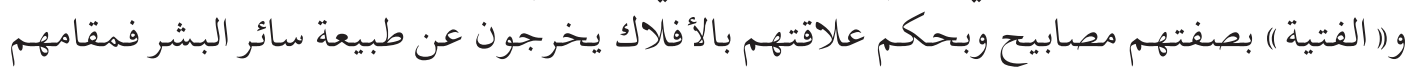

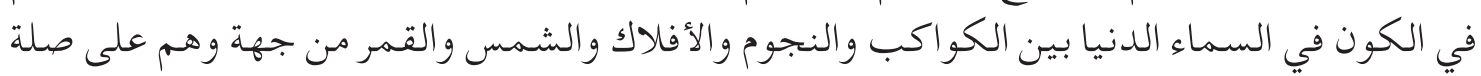

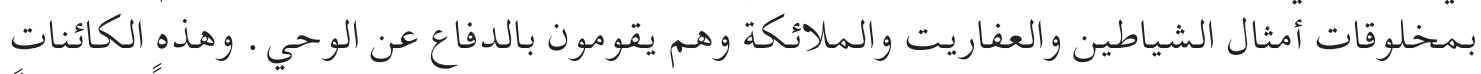

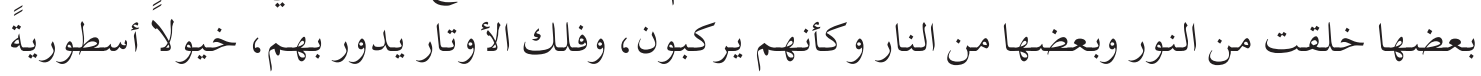

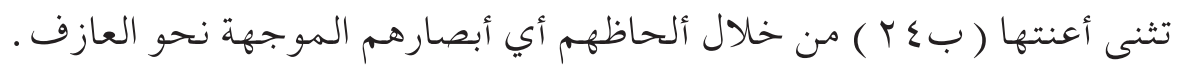

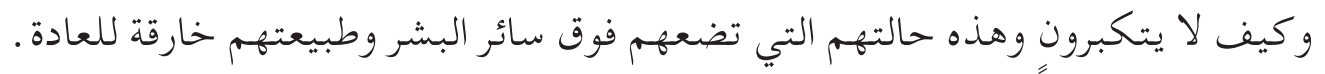

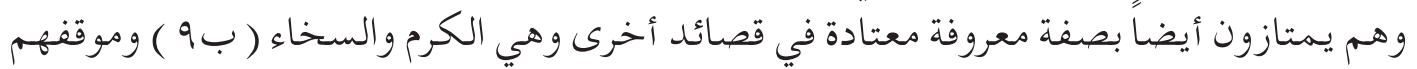

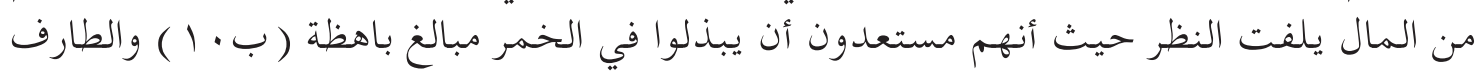

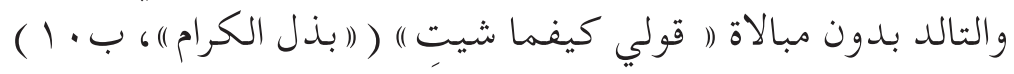




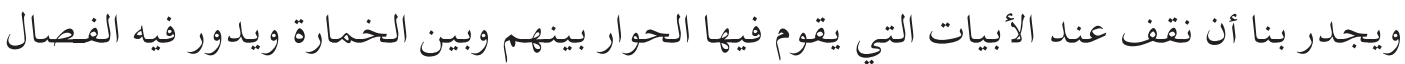

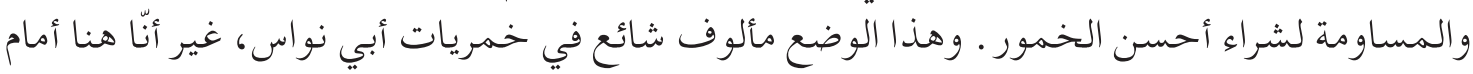

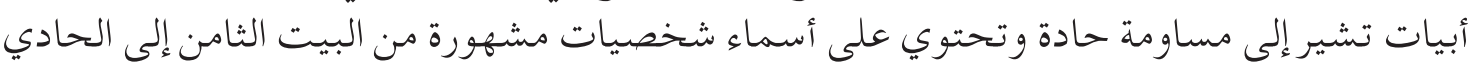

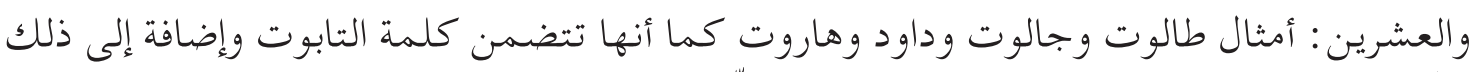

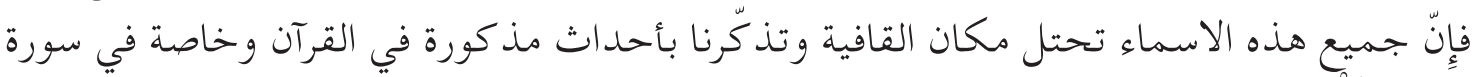

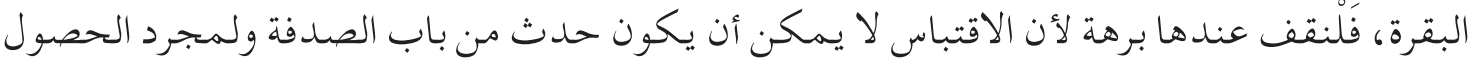

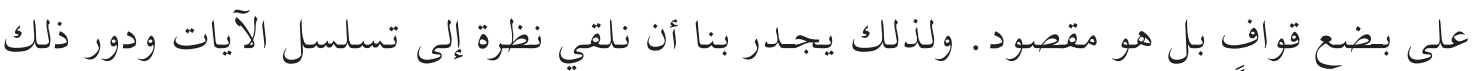

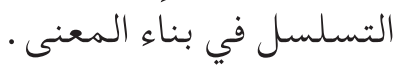

\section{تسلسل الآيات في سورة البقرة :}

سنحاول أن نكتشف من خلال تسلسل الآيات نوعية العلاقات القائمة بين النصين والتي تؤكد

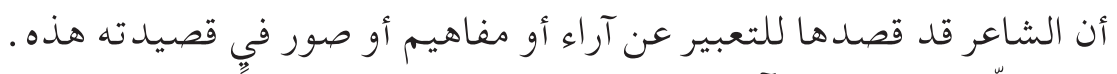

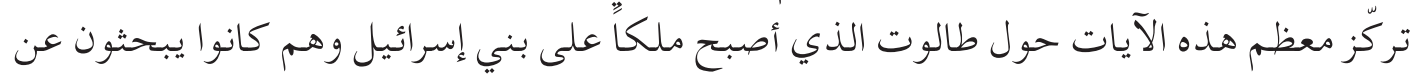

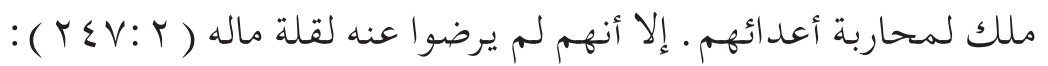

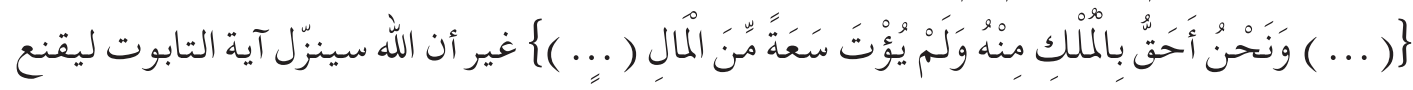

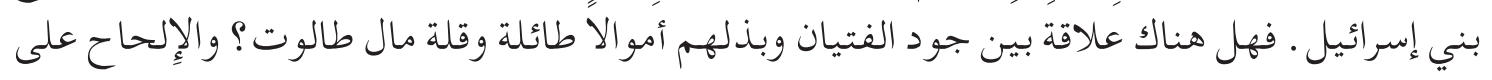
المال يسترعي الانتباه.

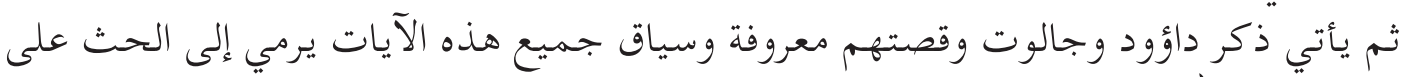

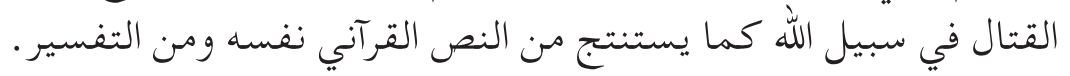

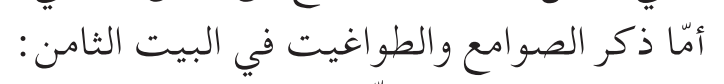

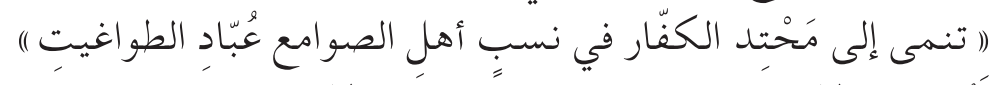

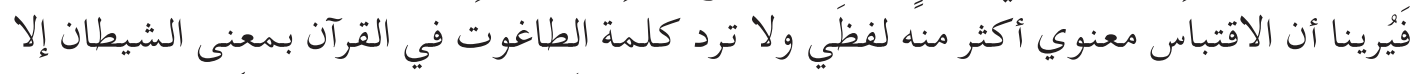

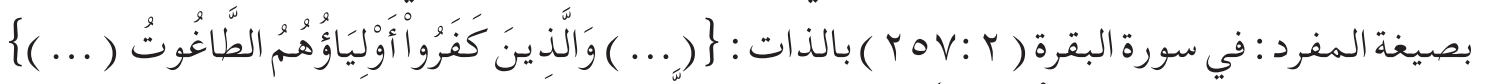

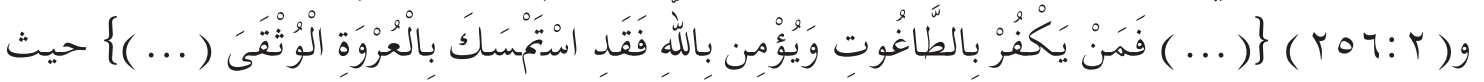

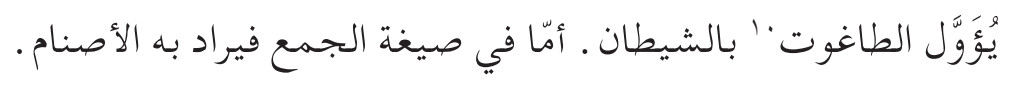

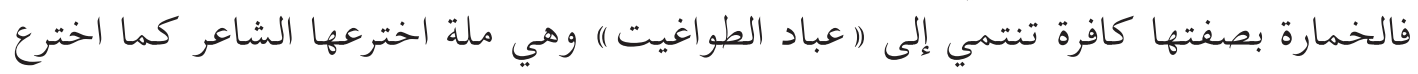

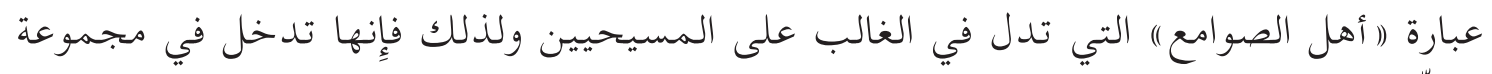

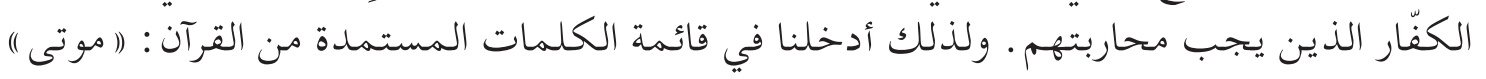




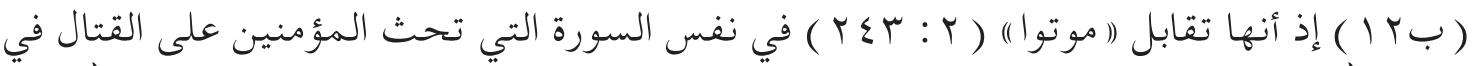

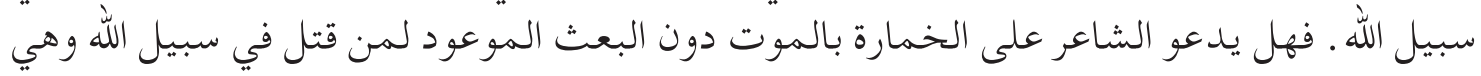

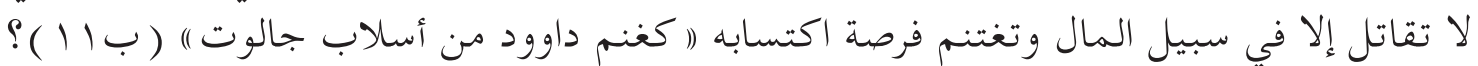

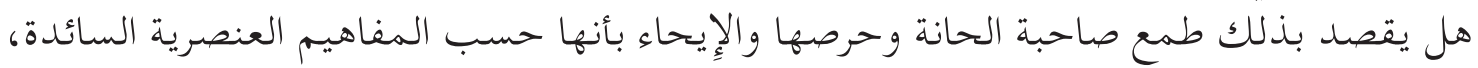

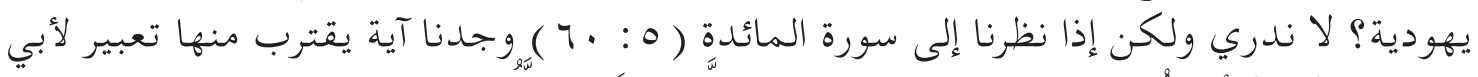

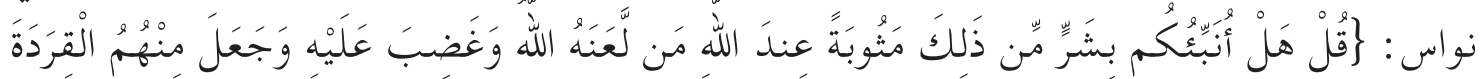

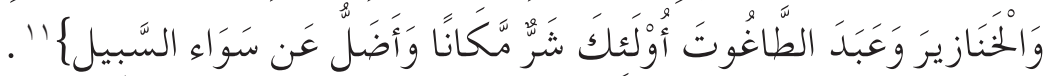

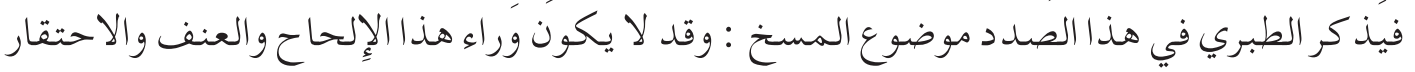

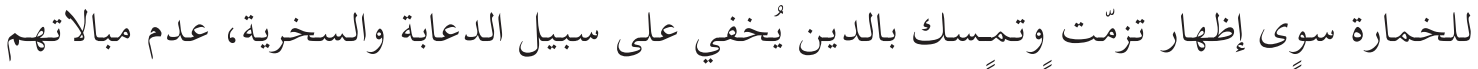

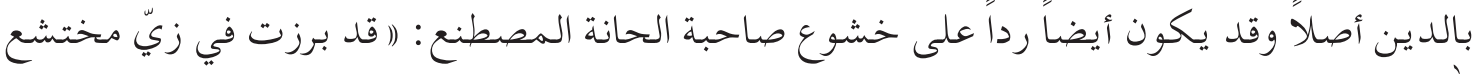

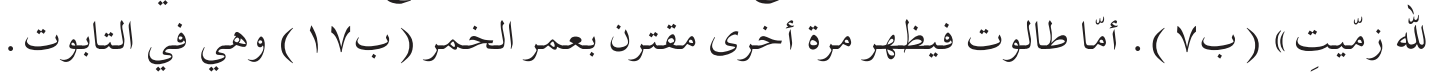

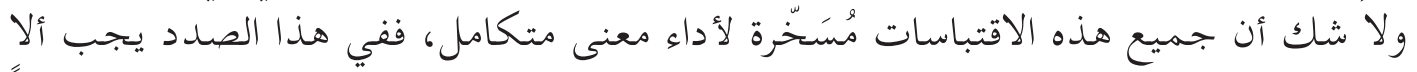

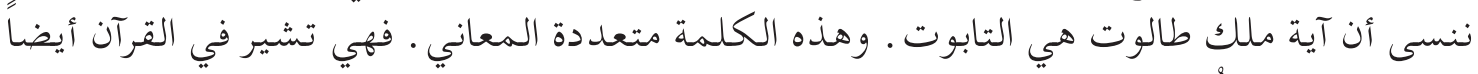

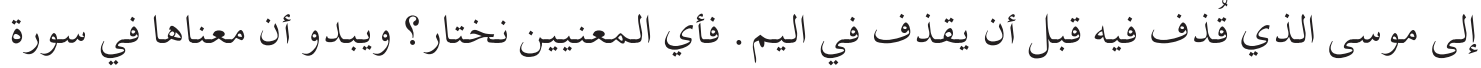

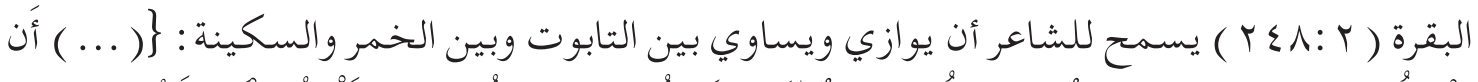

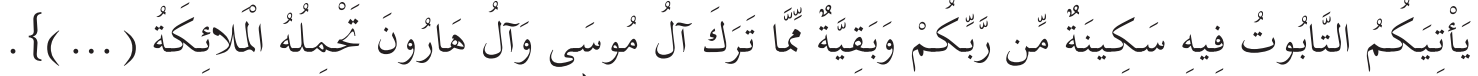

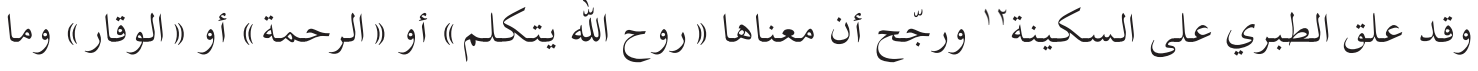

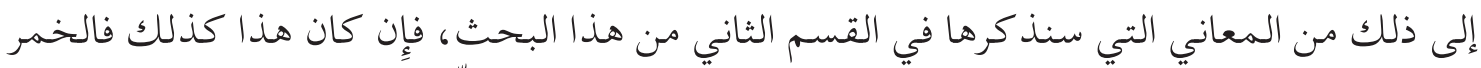

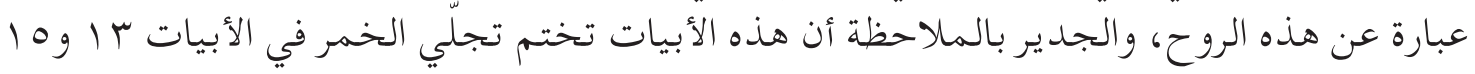

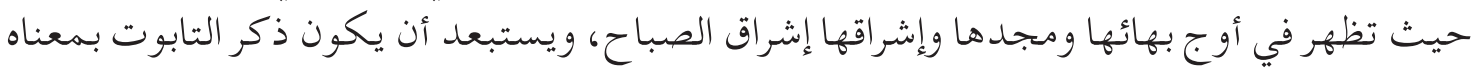

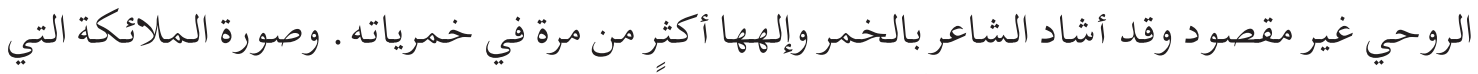

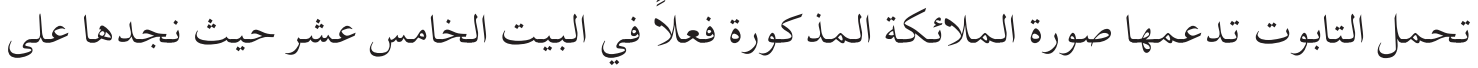

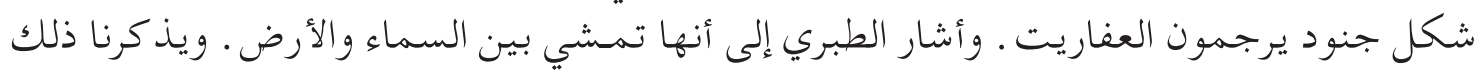

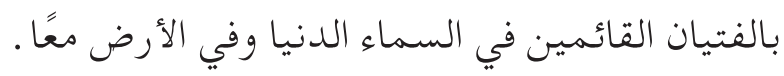

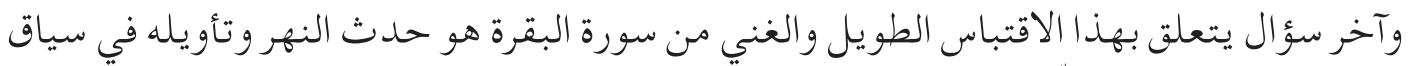

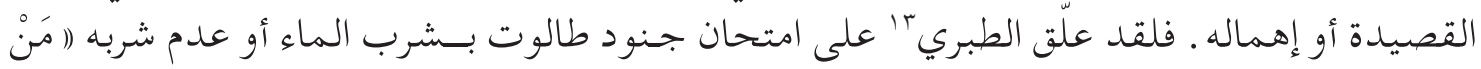

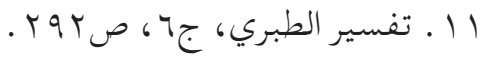

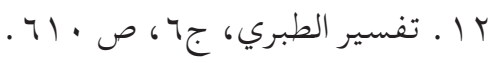

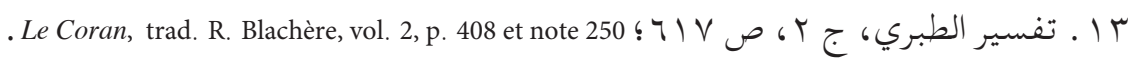


لم يـُق ماء ذلك النهر فهو منّي ) مشيراً إلى طريقة الشرب أي مَنْ شرب ماء النهر فاغترفه بيده غَرفة أنه

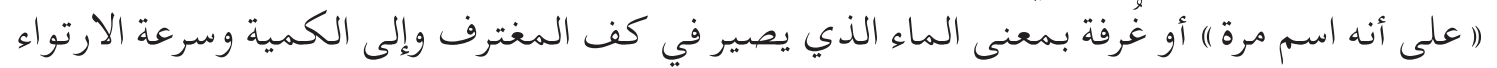

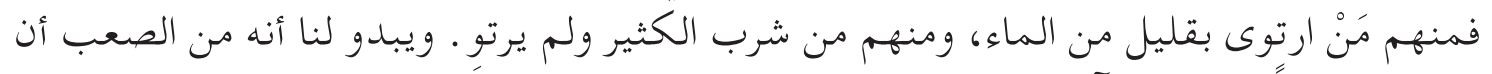

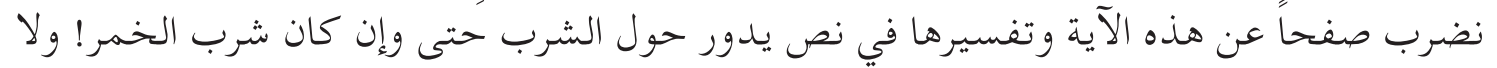

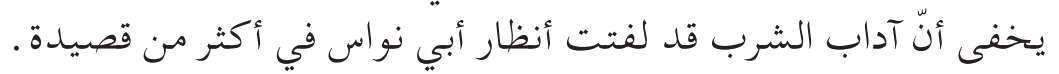

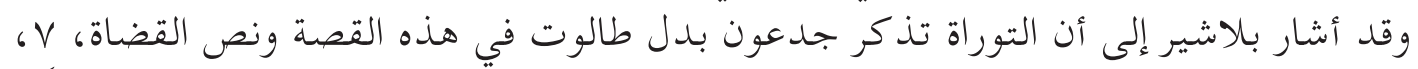

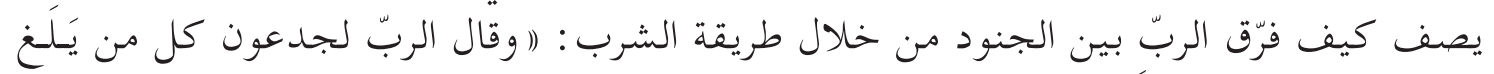

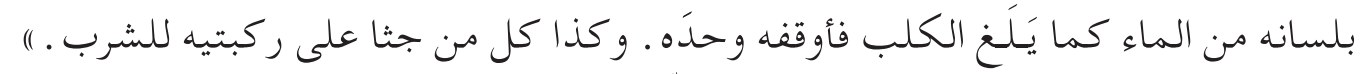

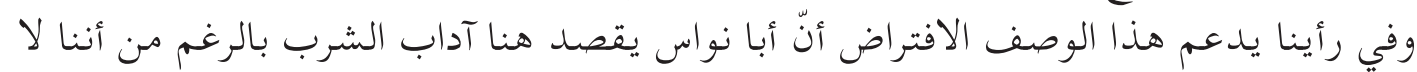

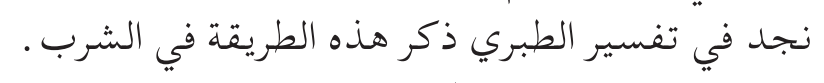

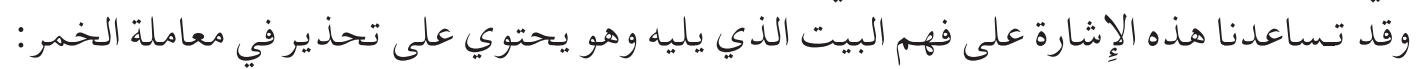

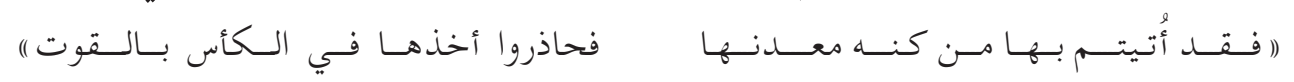

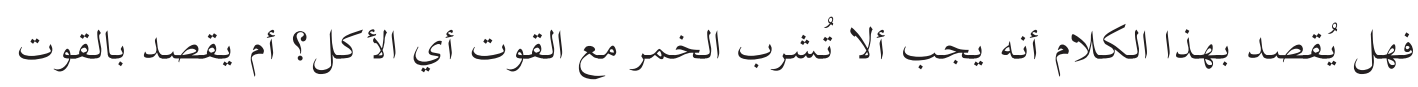

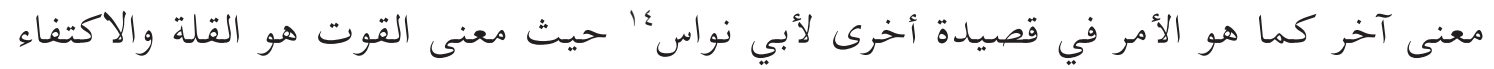

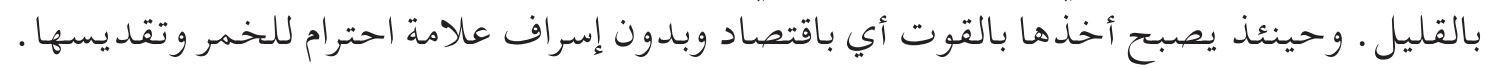

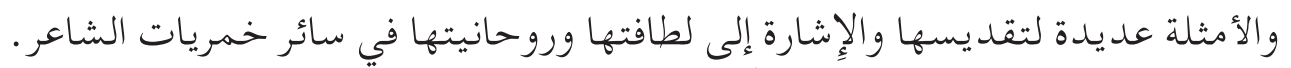

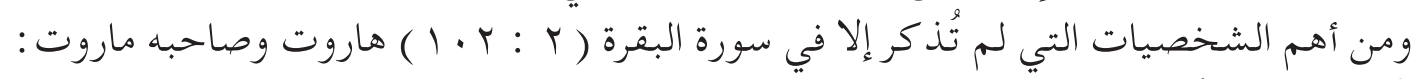

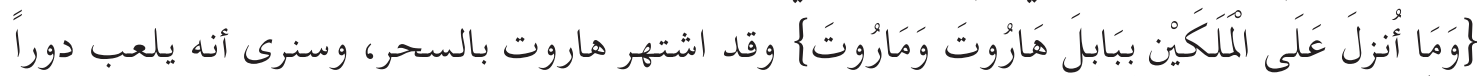

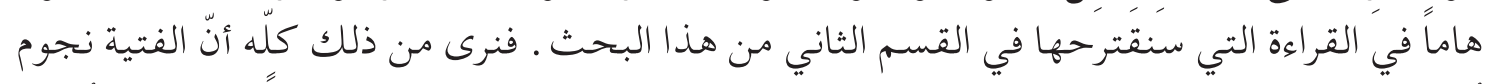

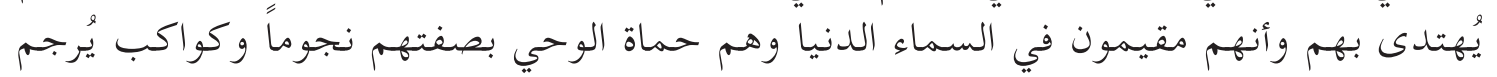

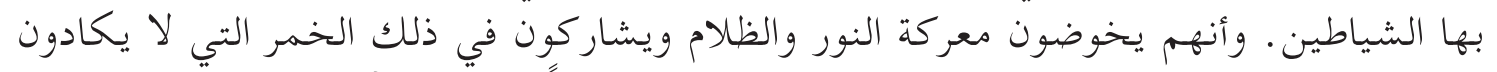

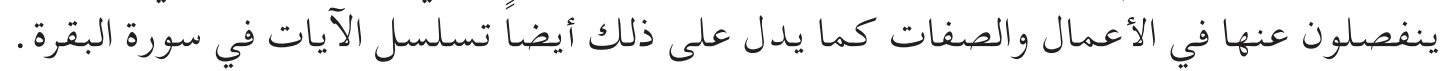

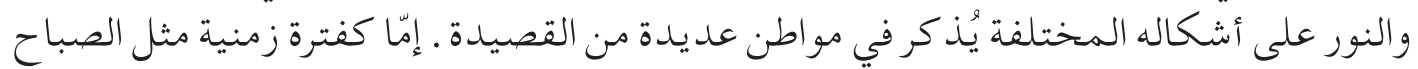
( ب ا - ع ا ) وإما كصفة للخمر : (ا هي الصباح) ) وليس هناك تعبير أقوى للتسوية بينها وبين النور :

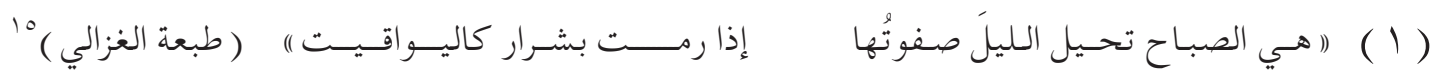

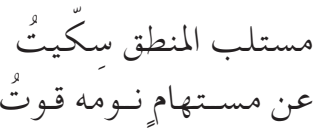

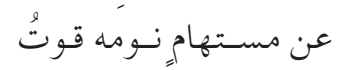

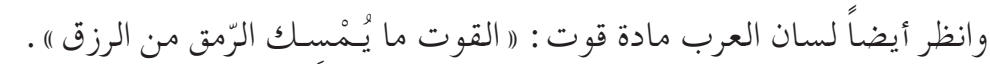




$$
\text { ويخـتلف هنا البيت حسب الطبعات . }
$$

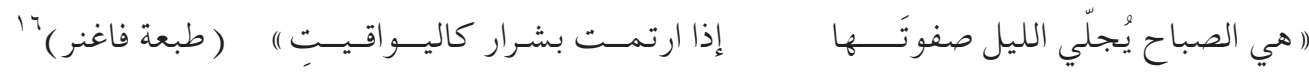

ونظراً لطبيعة الخمر كما تظهر في الأبيات ع 1 -17 ا نفضل القراءة الأولى التي تتماشى مع نشاط

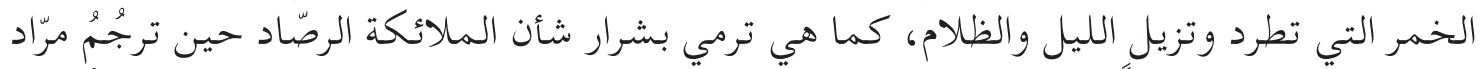

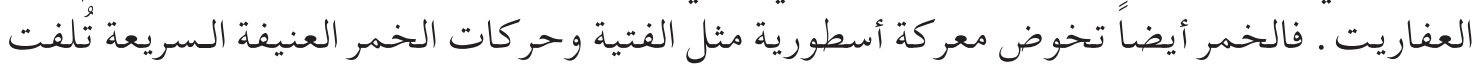

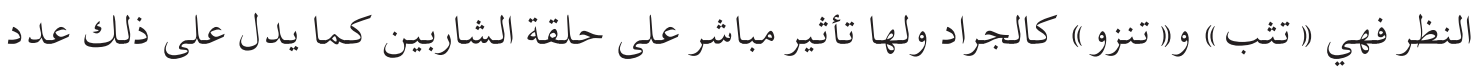

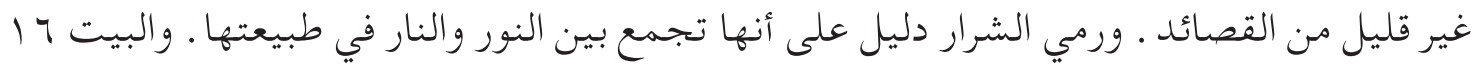

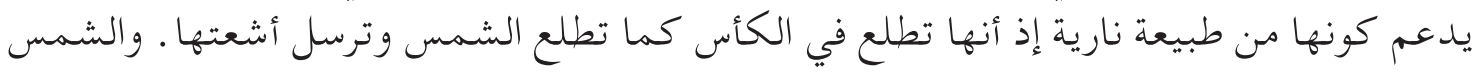

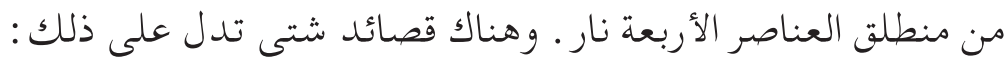

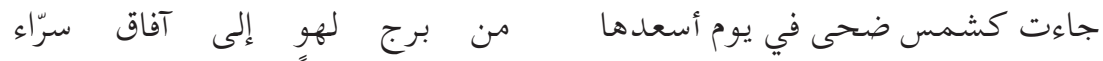

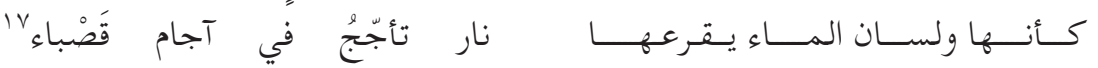

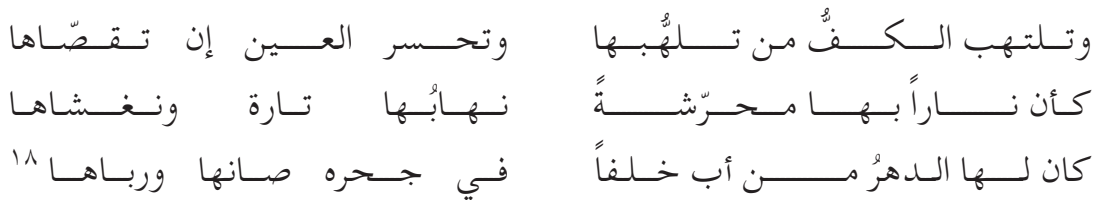

والخمر والفتية يشتركون إذن في صفات عد يدة وكلما تقدمنا في القصيدة وجدنا بينهم موازاة

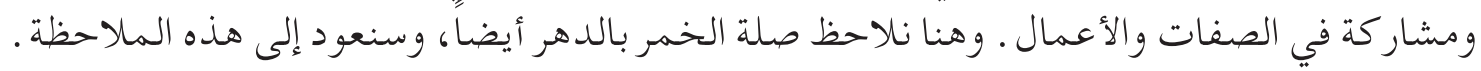

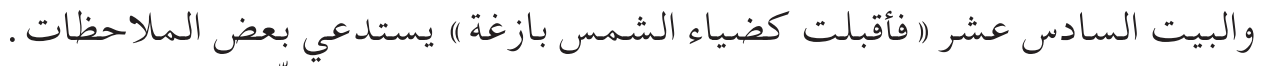

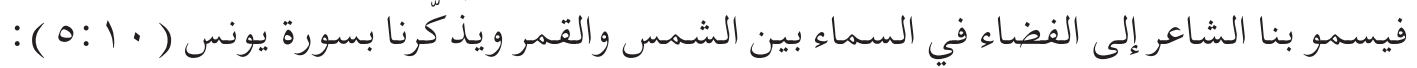

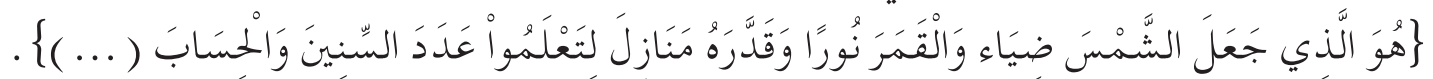

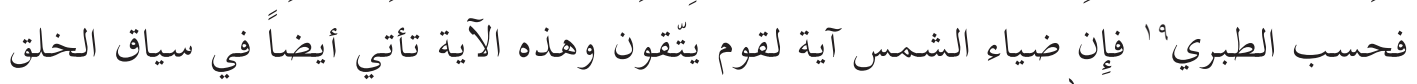

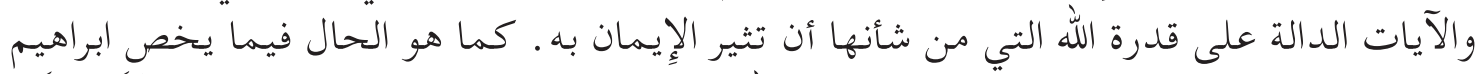

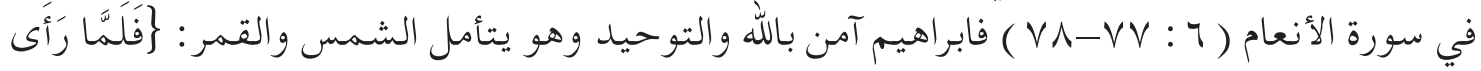

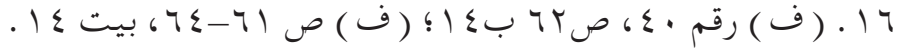

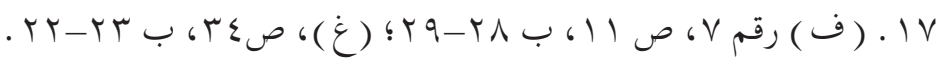

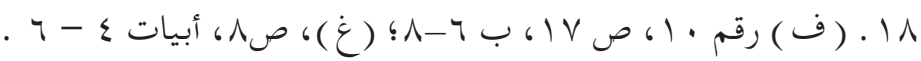

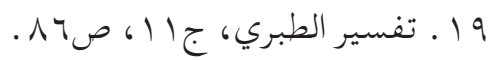




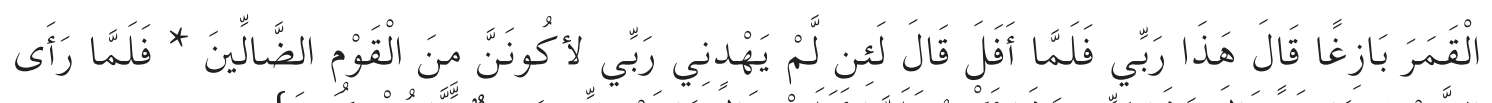

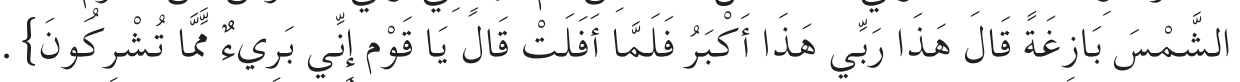

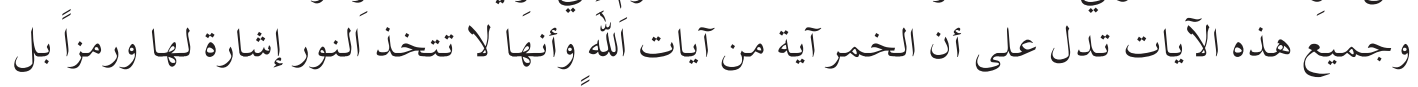

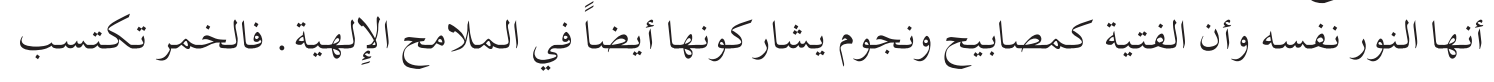
صفات الألوهية.

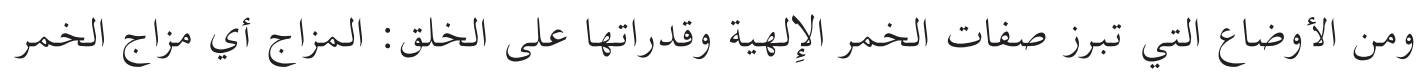

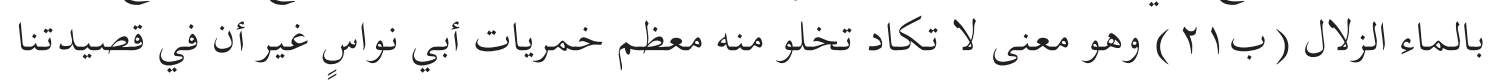

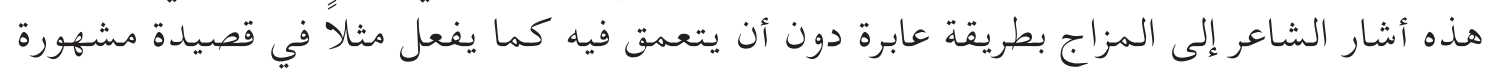

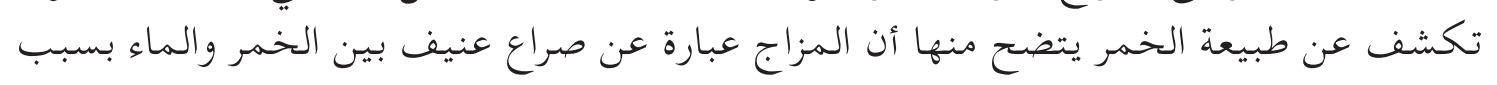

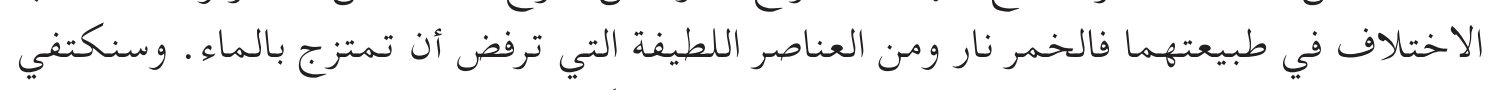

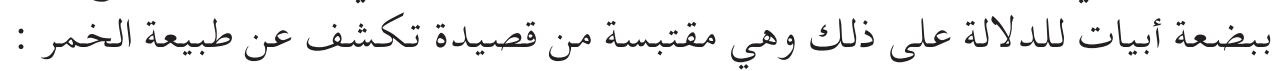

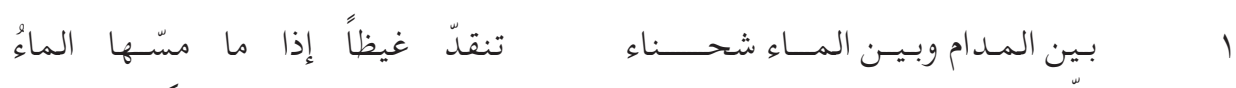

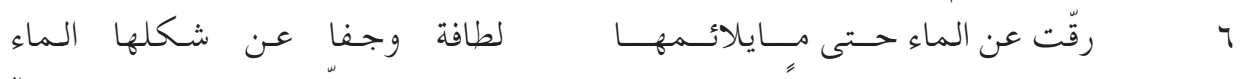

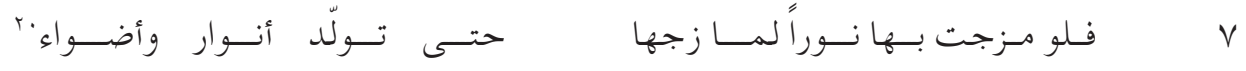

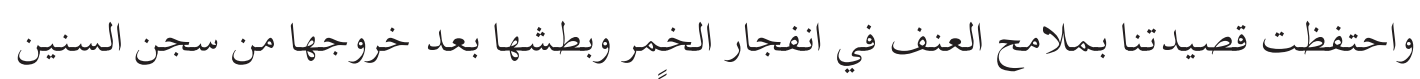

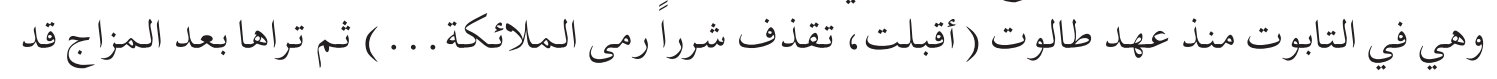

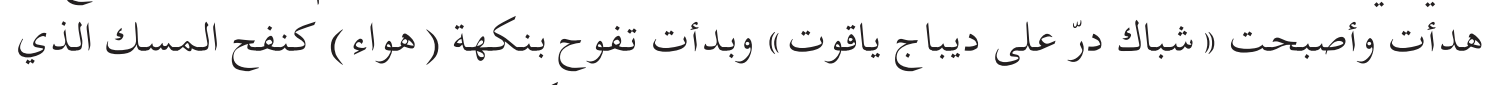

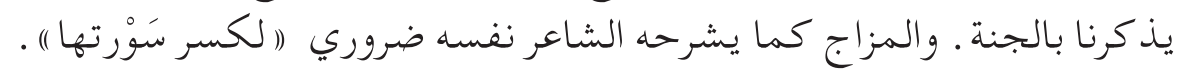

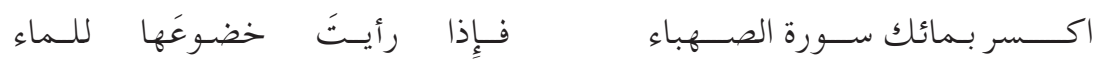

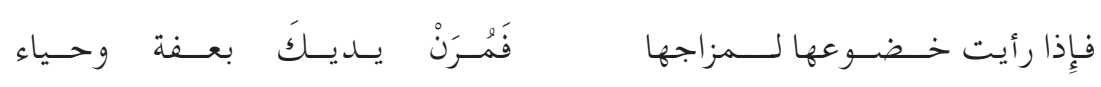

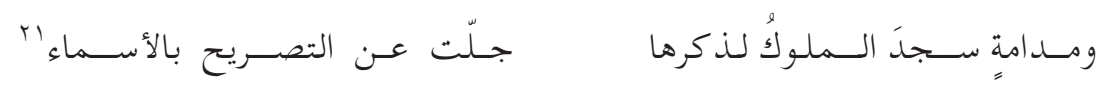

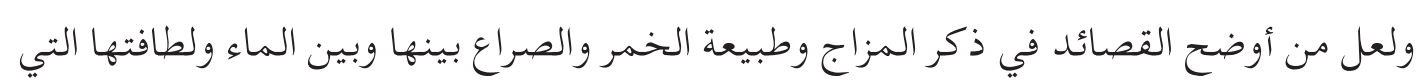

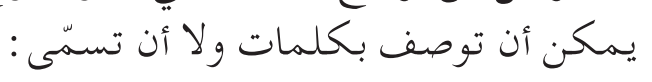

$$
\text { r. }
$$

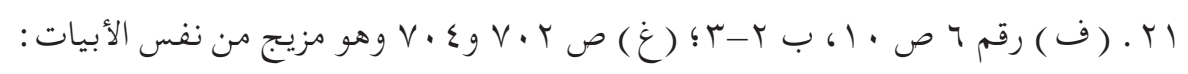

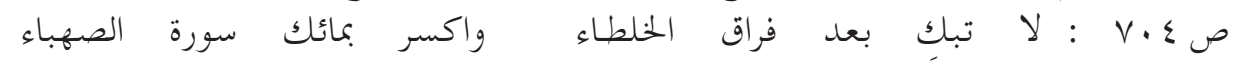

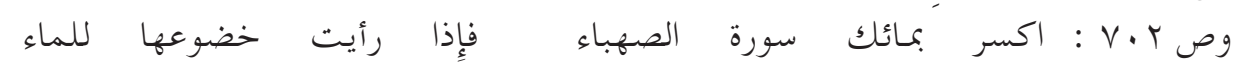

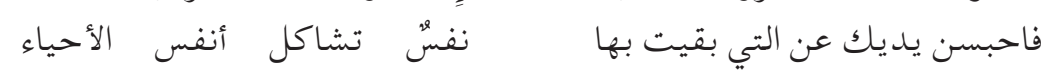




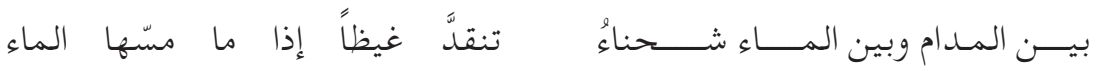

$$
\text { التي ذكرنا بعض أبياتها . آنسان }
$$

وآخر ملاحظة تدعم ألوهيتها هي العلاقة بين الخمر والدهر فهي قد بلد رضعت معه ثدياً واحداً

مها يدل على أزليتهما.

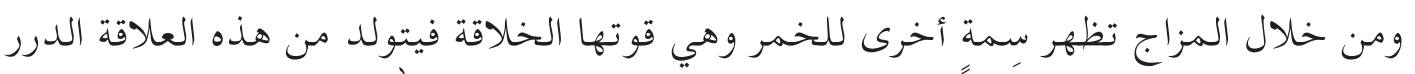

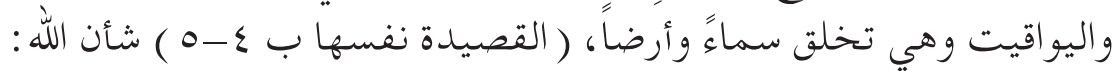

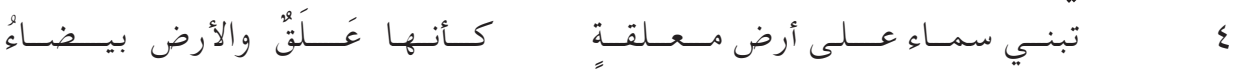

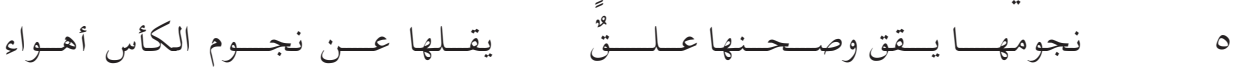

أمّا في قصيدتنا فيجب أن نلاحظ أن الاقتباسات العديدة من النص النموذج ( القرآن ) تبني

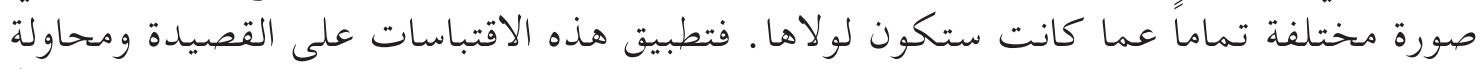

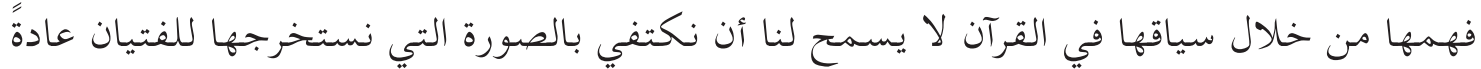

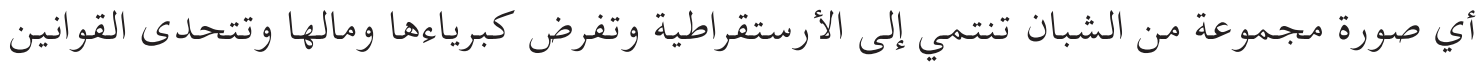

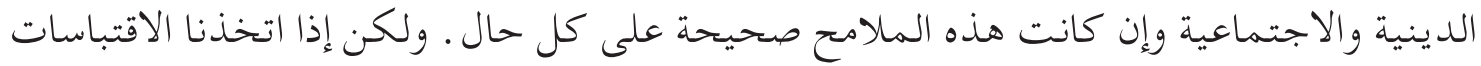

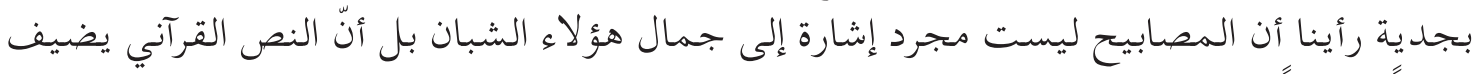

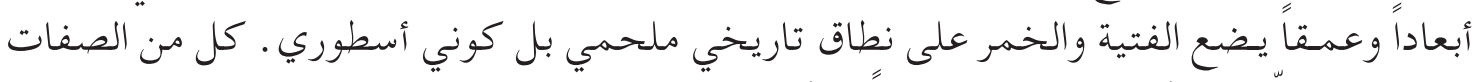

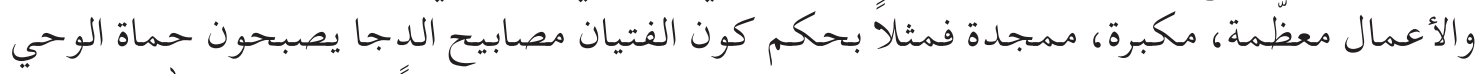

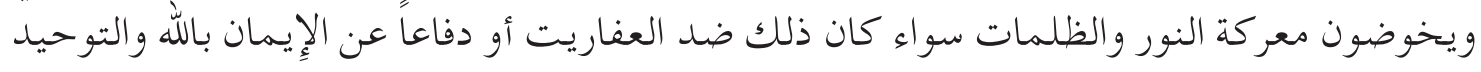

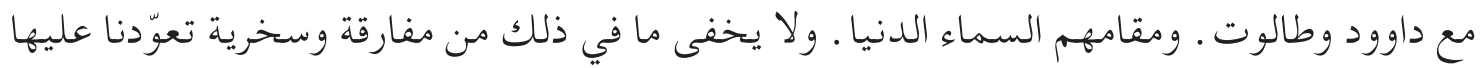

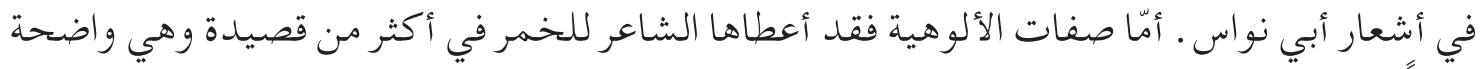

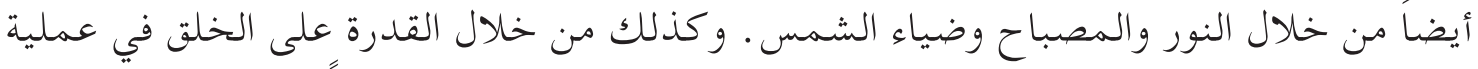

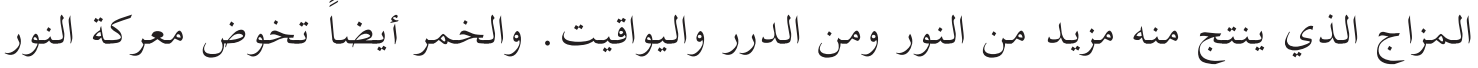

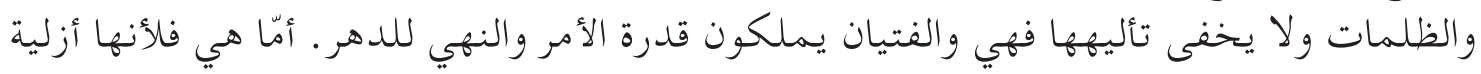

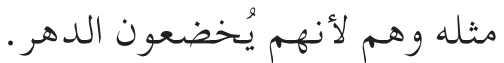

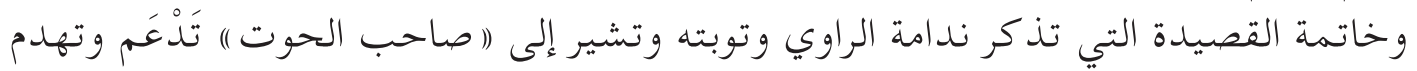

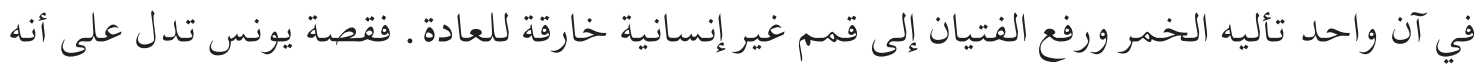

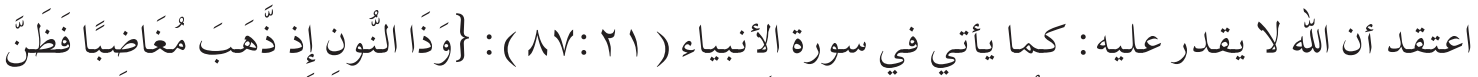

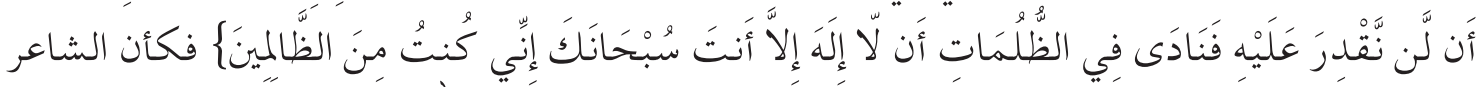

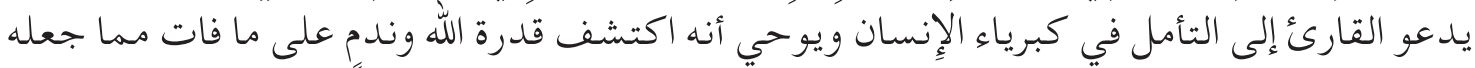

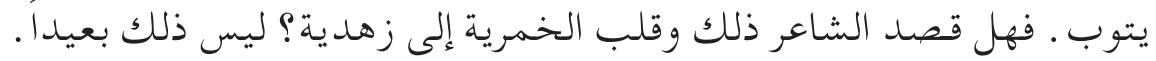




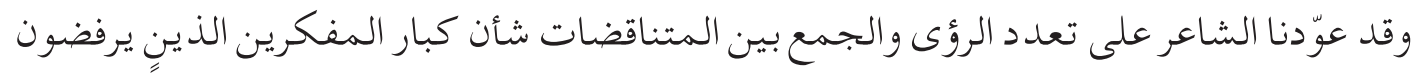

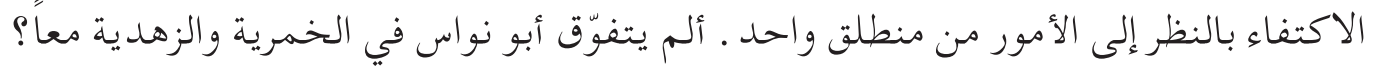

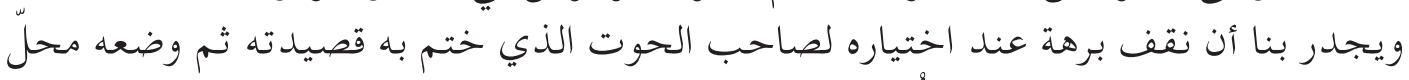

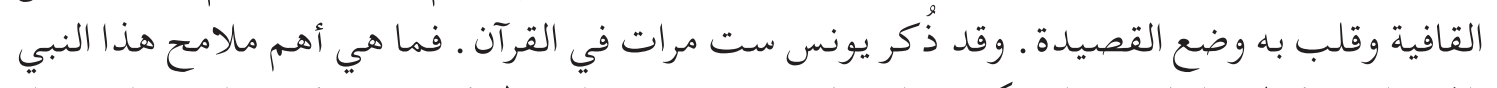

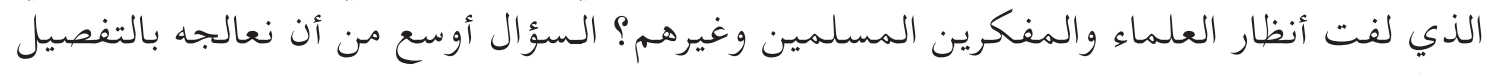

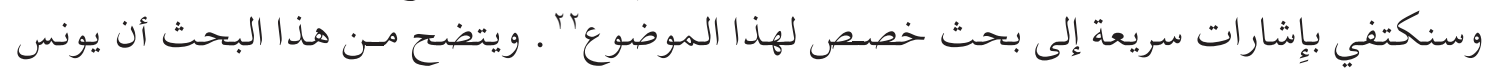

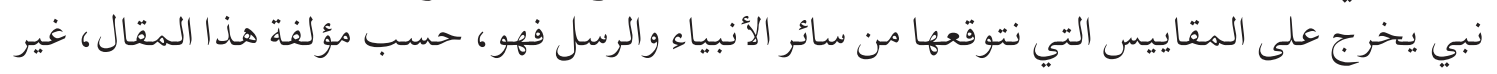

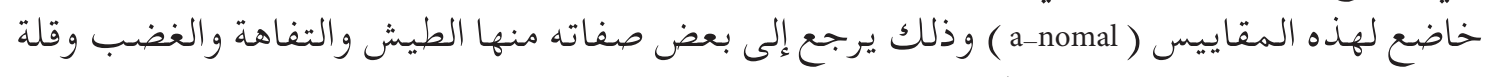

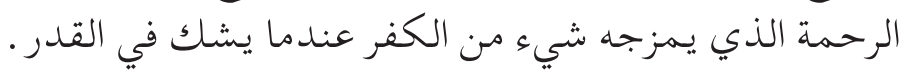

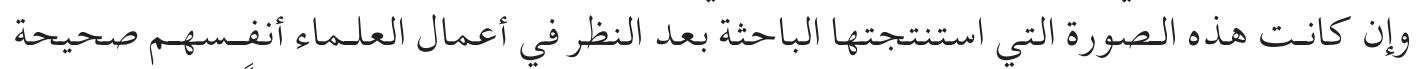

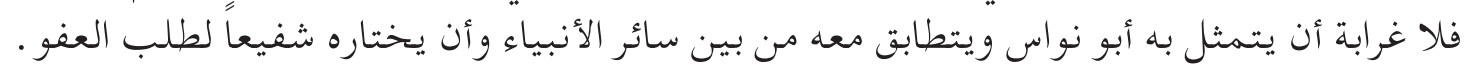

\section{قر اعة مختلفة ب}

ويمكننا أن نتساءل الآن هل يمكن أن تؤدي بنا القراءة المبنية على الاقتباسات المكثنفة من

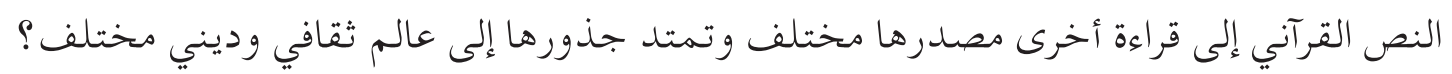

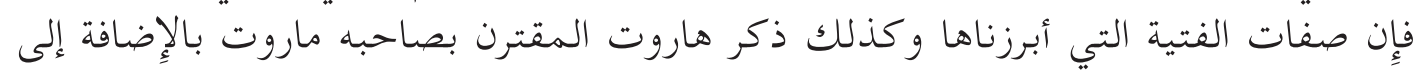

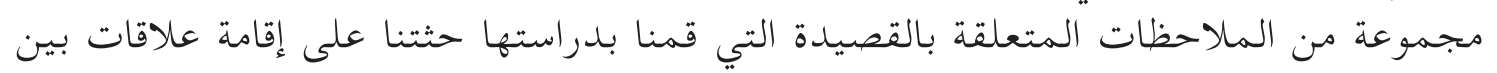

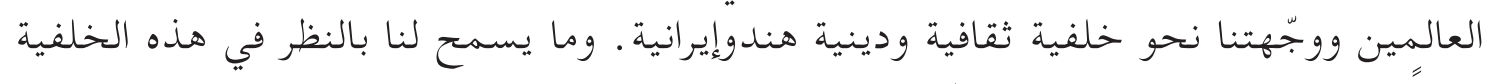

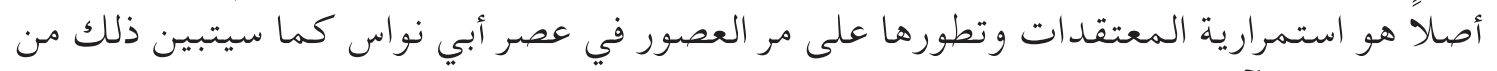

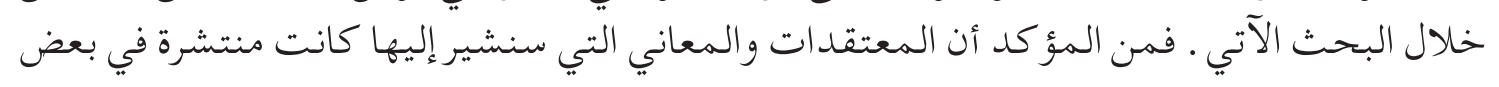

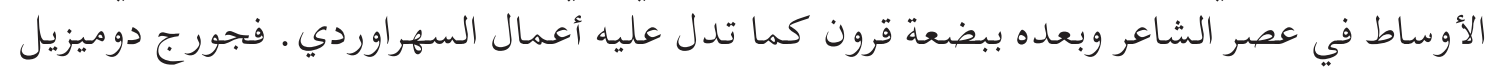

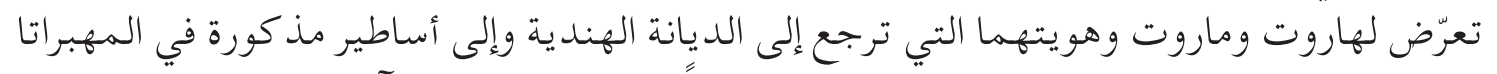
(MAHÂBHÂrata)

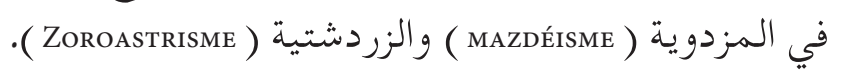

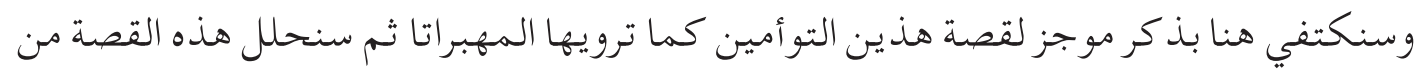
وجهة نظر قصيد تنا وفي مرحلة ثانية سنتناول صفات الفتية ونقارنها بصفات (ا فتية ماروت ) ) الفيدية ( وع́diQue ) 
أمّا في مرحلة ثالثة فسنلقي نظرة إلى طور من أطوار قصة إندرا الإِله المقاتل وإختِفائه في مياه

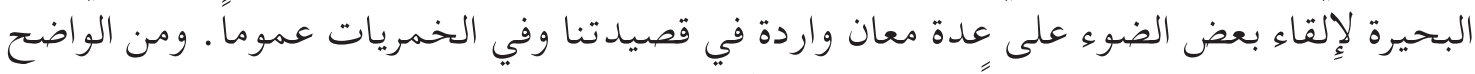

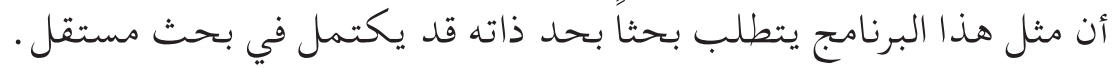

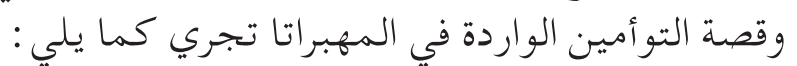

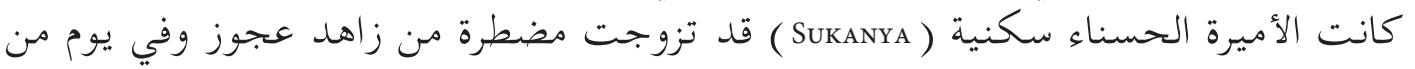

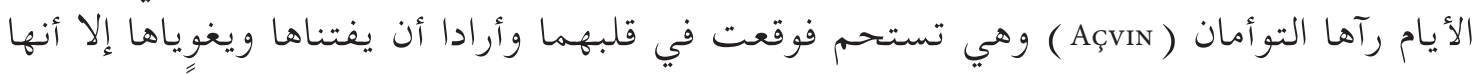

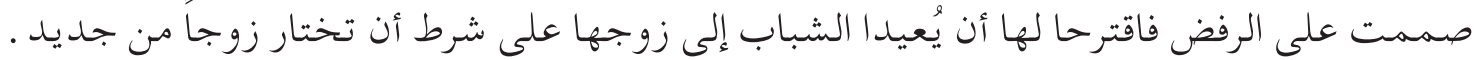

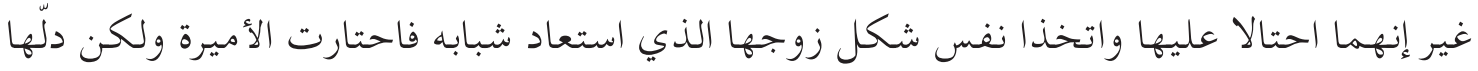

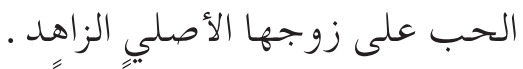

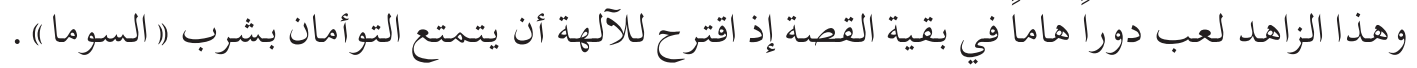

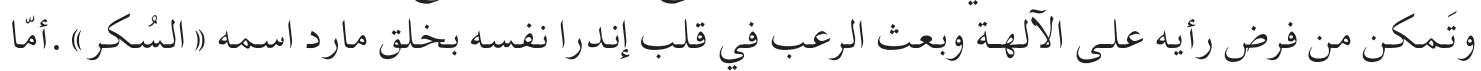

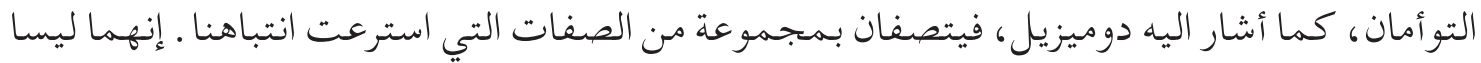

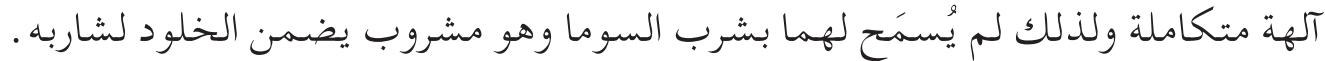

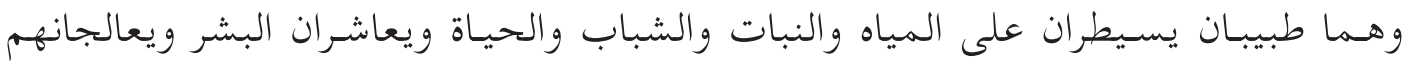

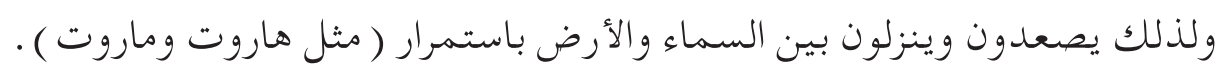

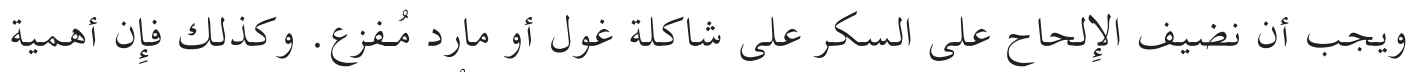

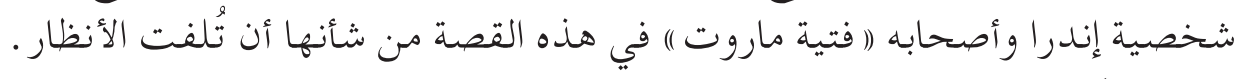

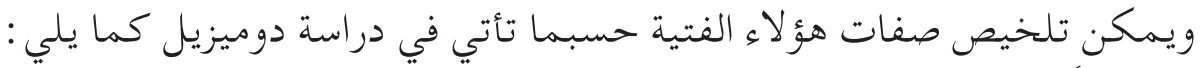

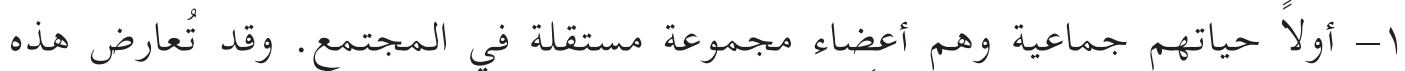

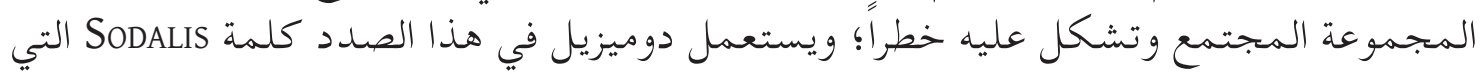

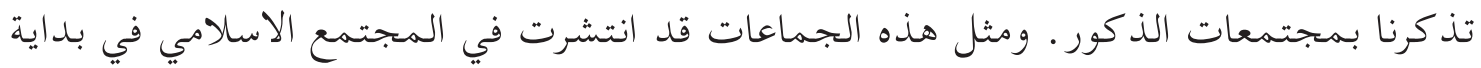

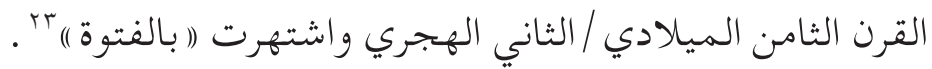

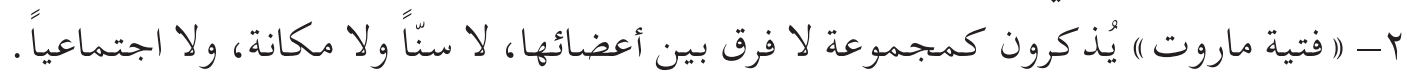

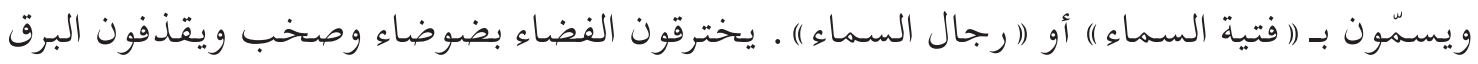

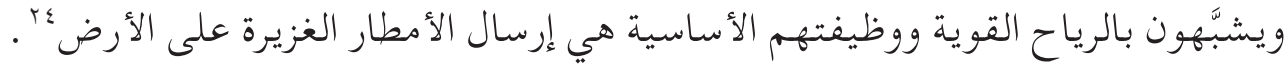

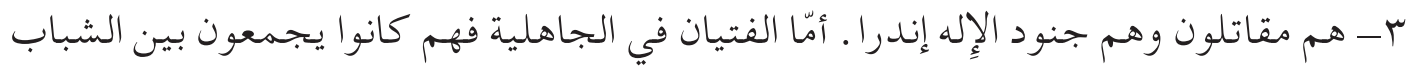
و والقتال.

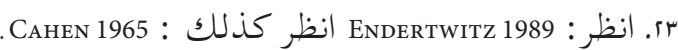

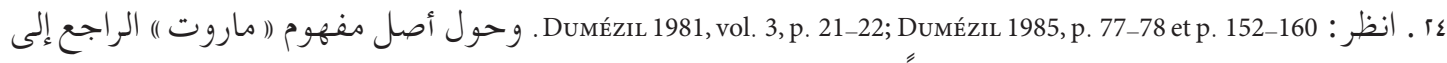
ما قبل القيدا وتطوره في الأقيستا أنظر أيضاً : Puech 1947, p. 221-225. 


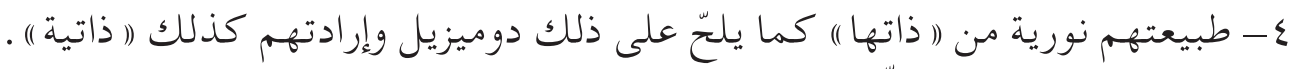

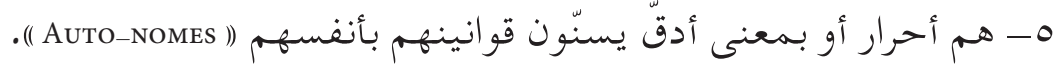

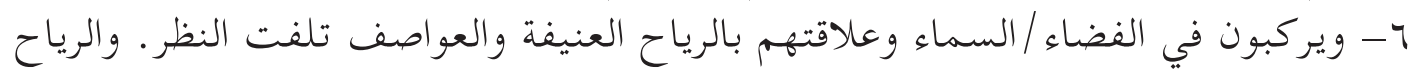

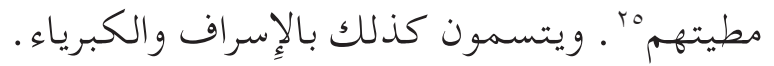

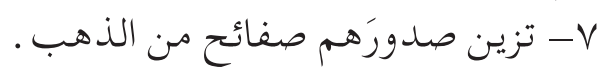

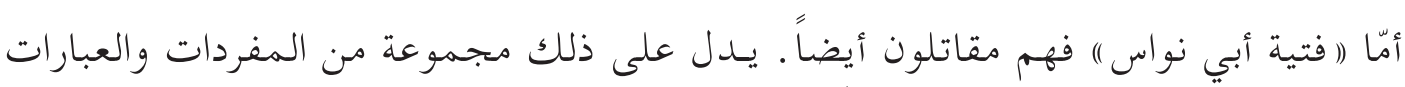

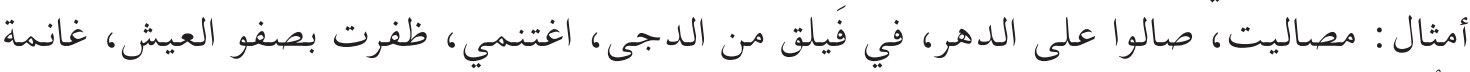

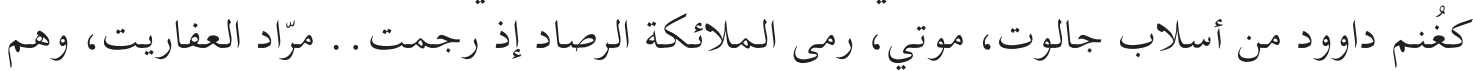

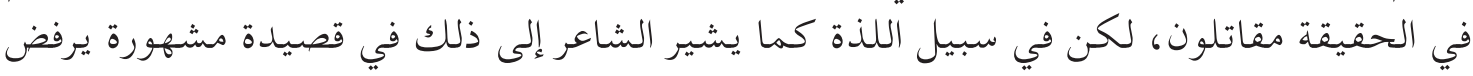

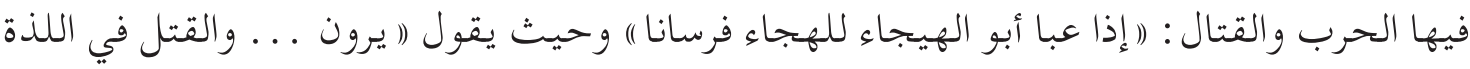

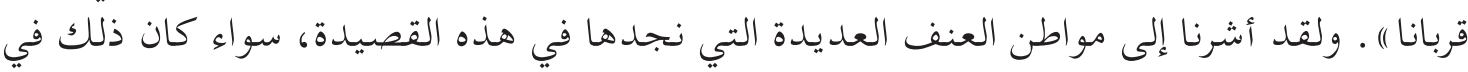

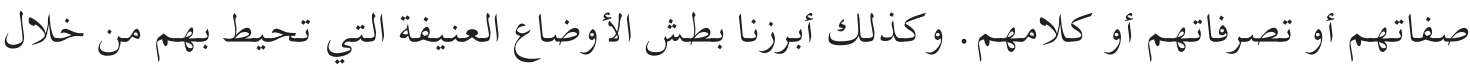

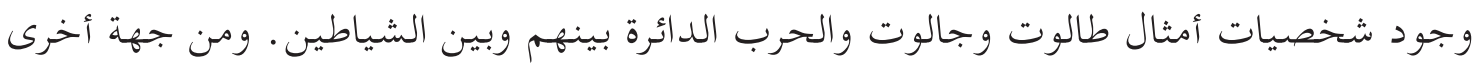

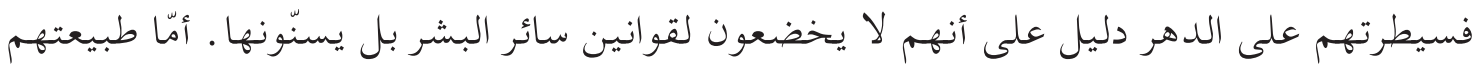

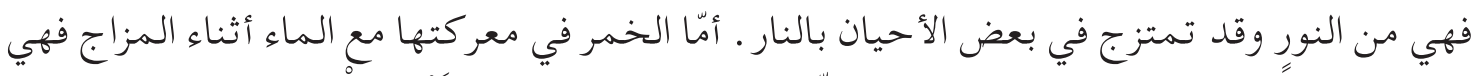

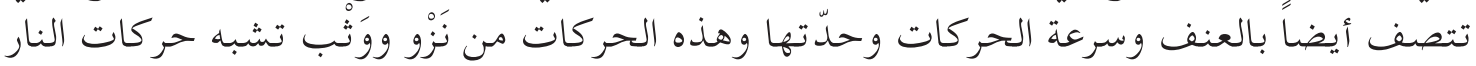

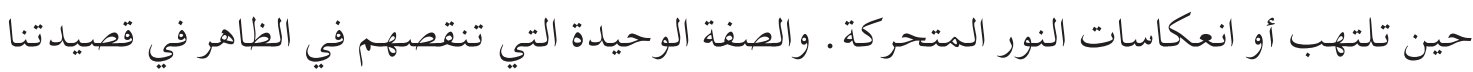

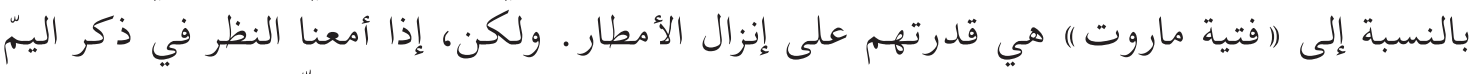

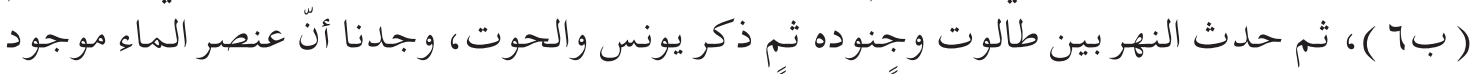

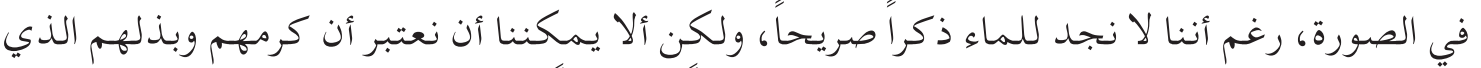

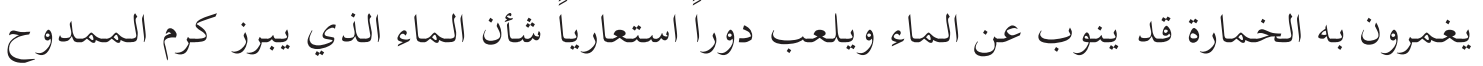

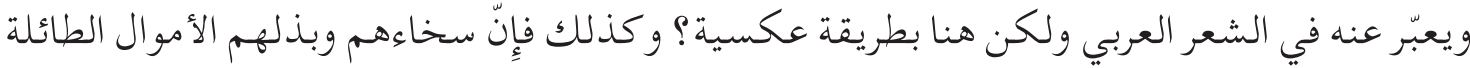

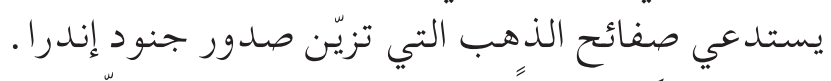

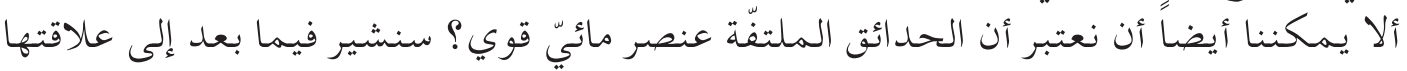

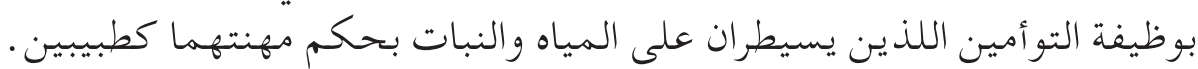

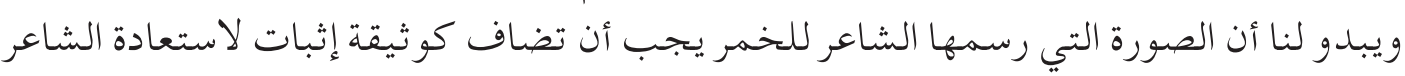

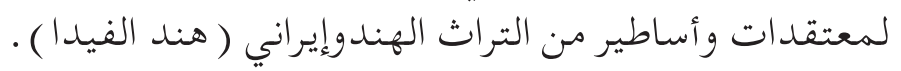




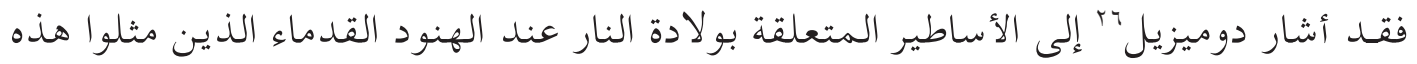

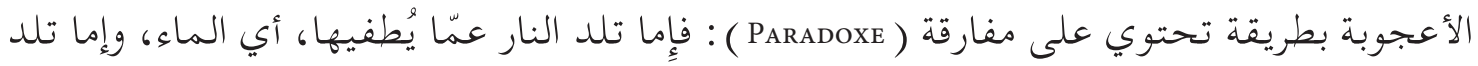

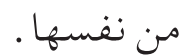

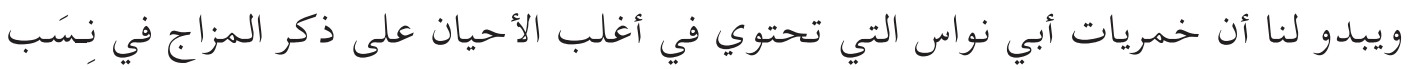

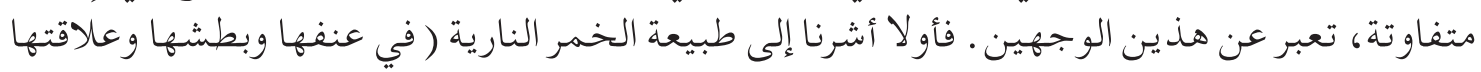

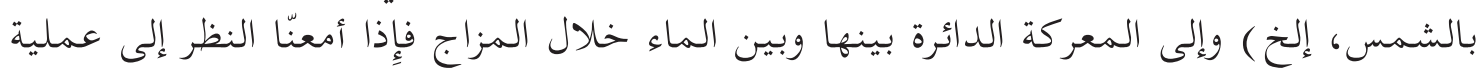

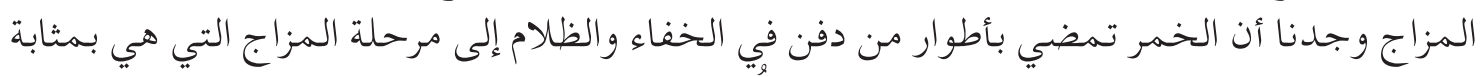

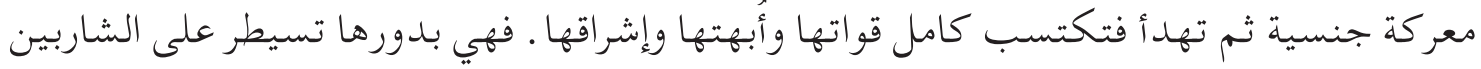

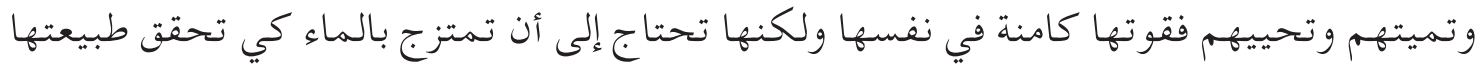

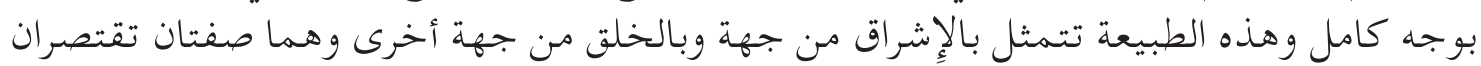
على الله.

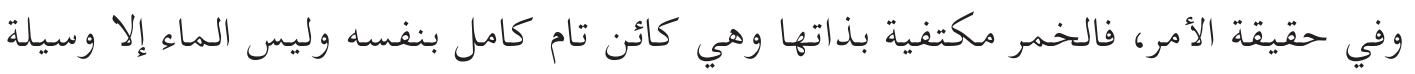

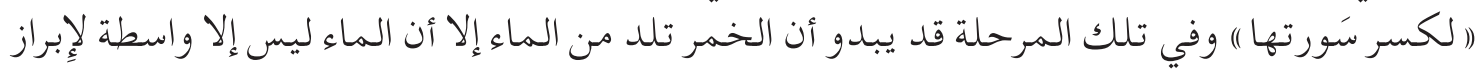

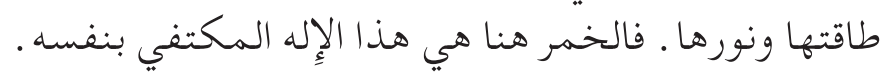

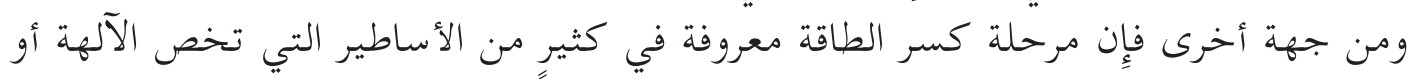

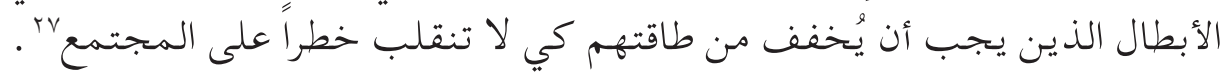
إن إندرا:

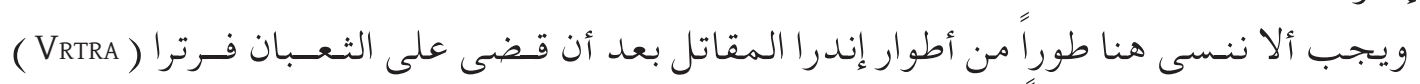

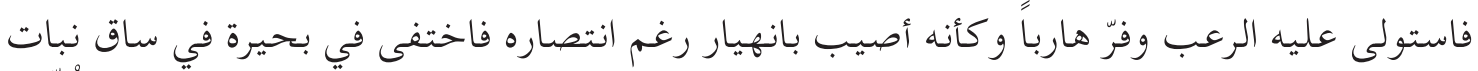

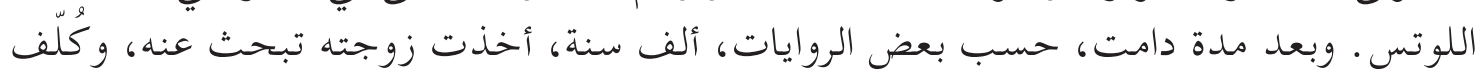

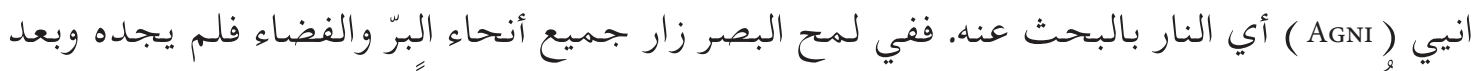

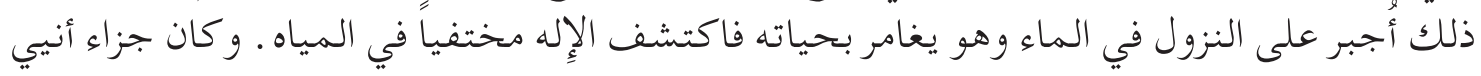

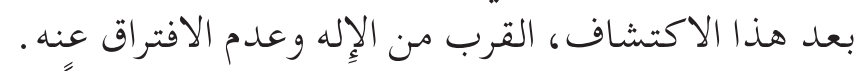

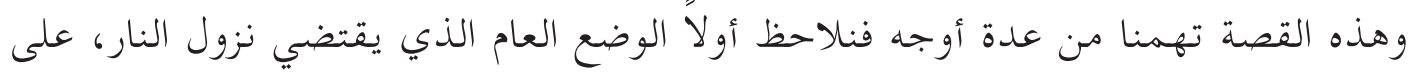

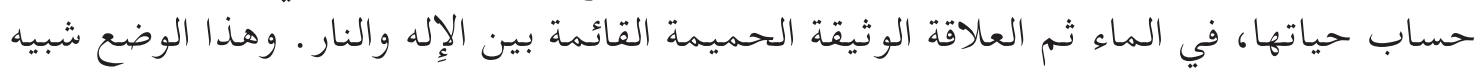

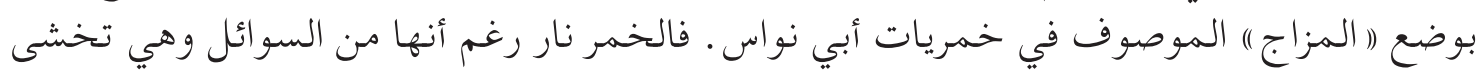

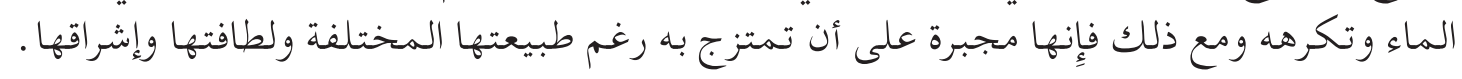
والبيت الذي ذكرناه سابقا :

I1 أنظر : DumÉzIL 1981, vol. 3, p. $21-27$ IV 


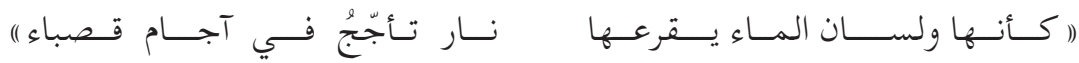

يكتسب دعنى يتجاوز مجرد الصورة الشعرية و كأنه يمثل قصة إندرا. فالقصباء أي المكان

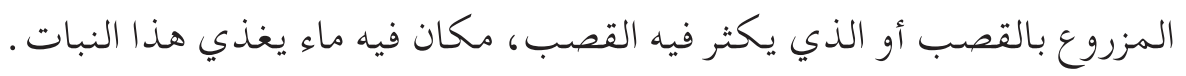

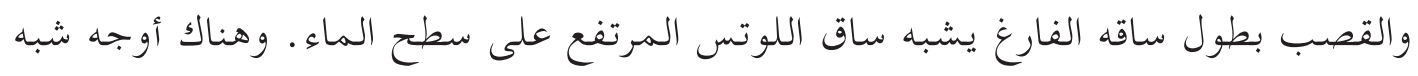

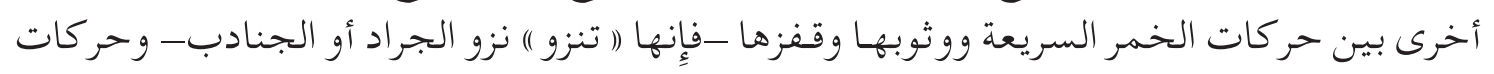

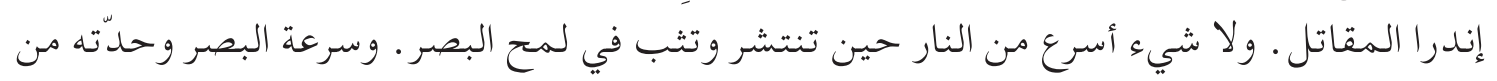

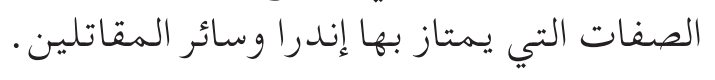

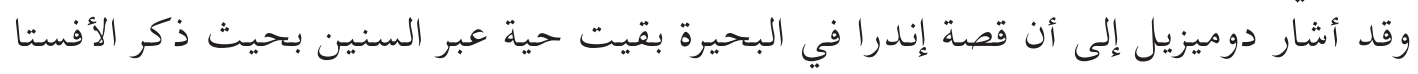
(AvESTA)

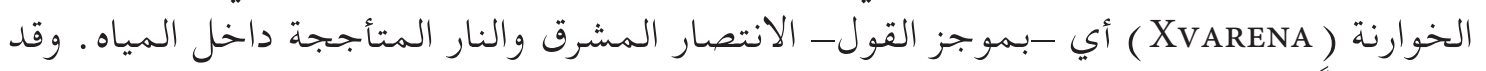
ذكره أيضاً نشيد يخاطب السوما ( أي المشروب المقدس الذي الذي يضفي الخلود على شاربيه ) والذي

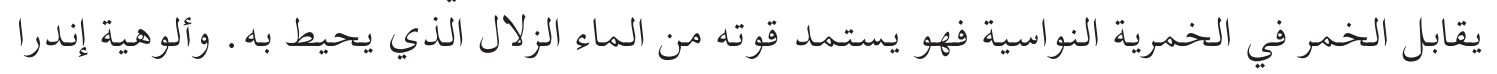

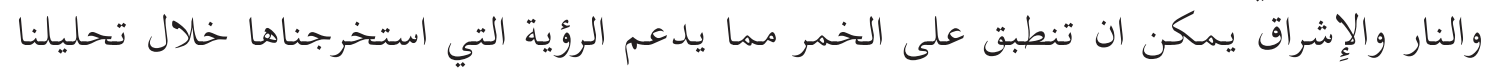

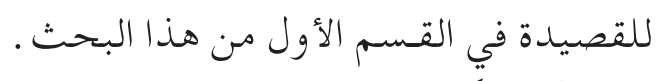

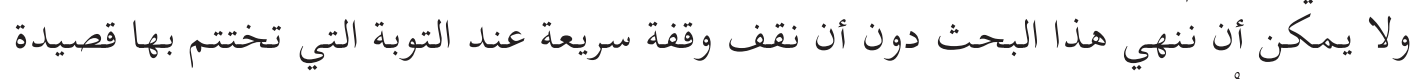

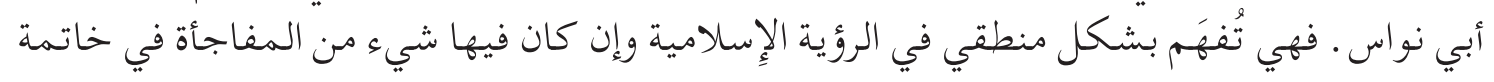

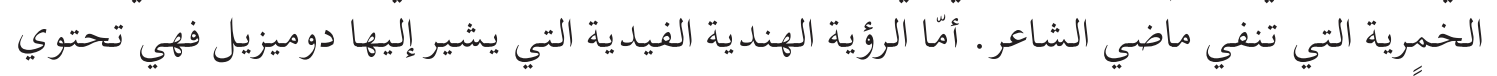

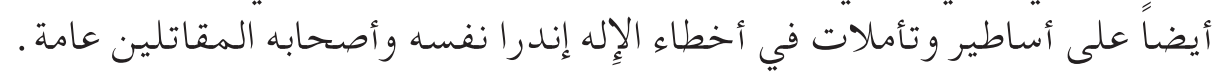

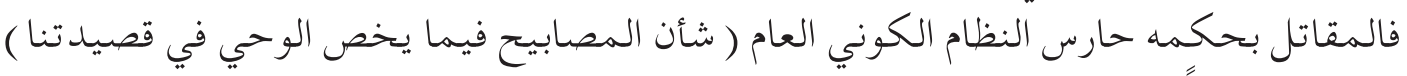

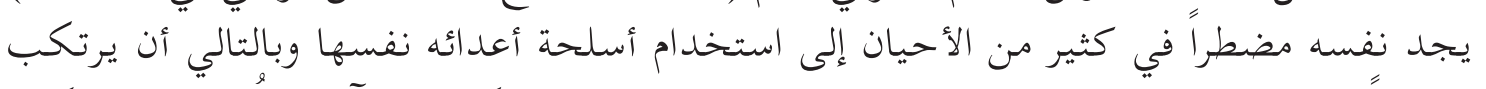

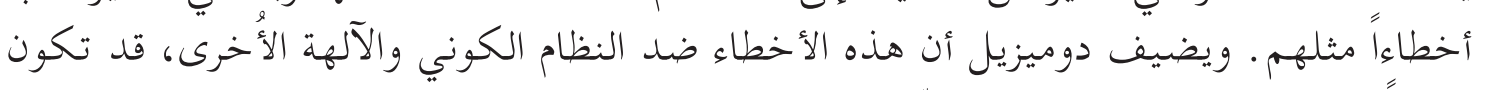

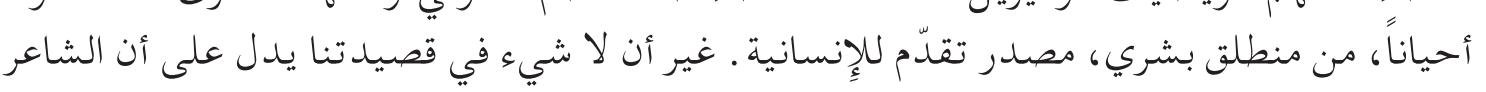

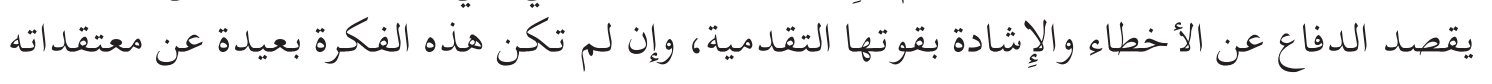

$$
\text { حسبما نجدها في رؤية الشاعر العامة للحياة. }
$$

وأشرنا إلى هذه النقطة (أي أخطاء المحارب ) لأنها تكوّن ثلاثية فيما يـخصّ طبيعة (ا فتية

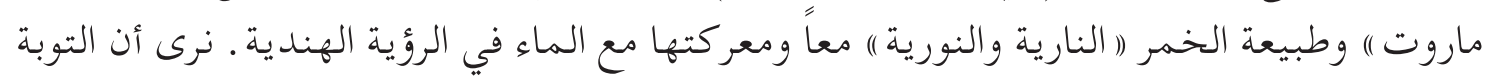


من شأنها أن تقوّي الموازاة التي وجدناها بين قصيدة أبي نواس والرؤية الهندوإيرانية التي يصفها

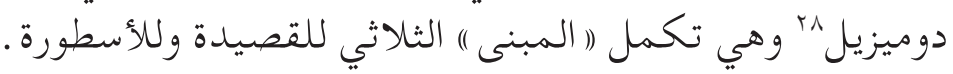

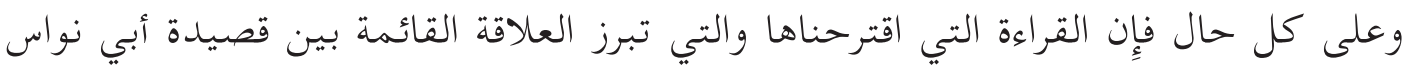

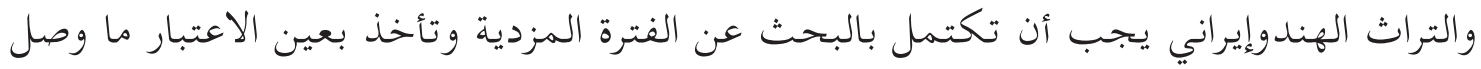

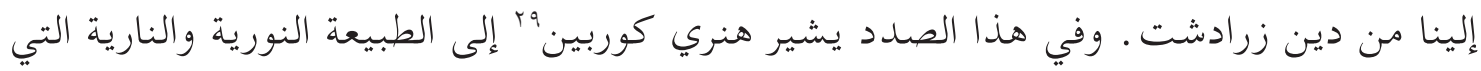

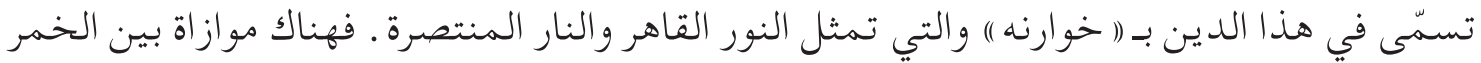

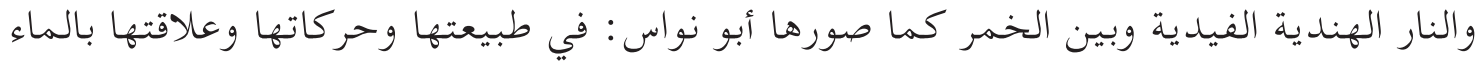

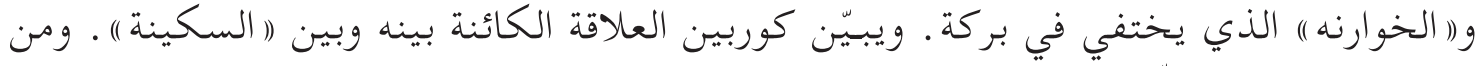

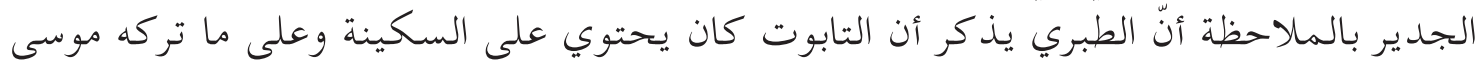

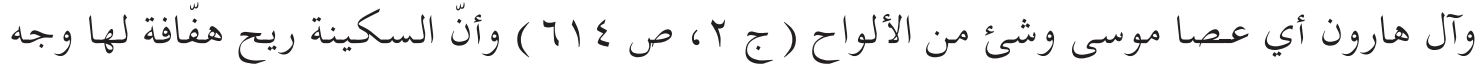

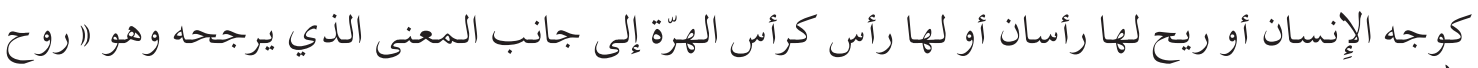

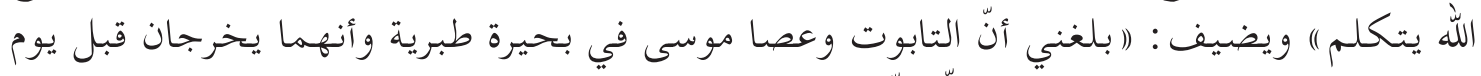

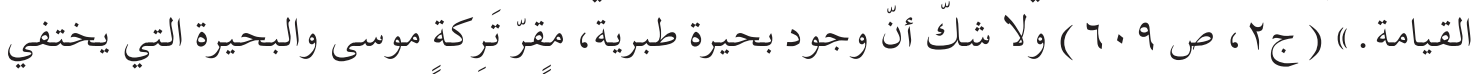

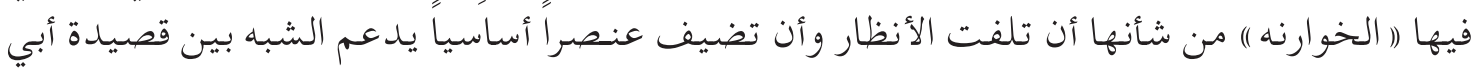

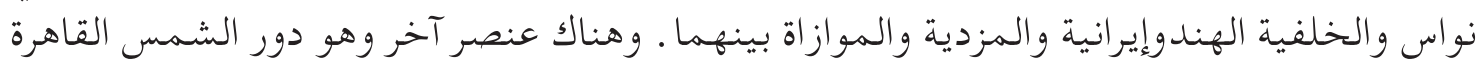
(SOL INVICTUS )

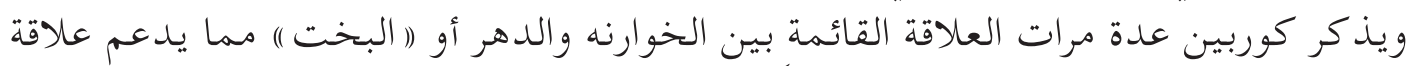

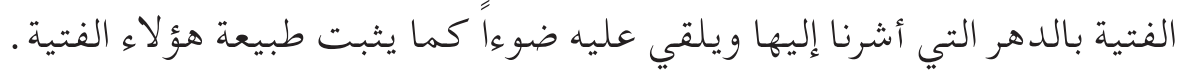

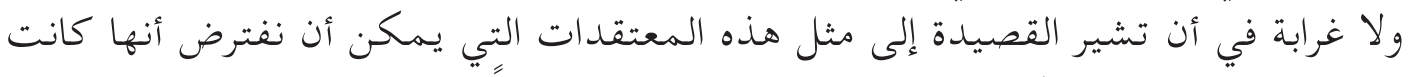

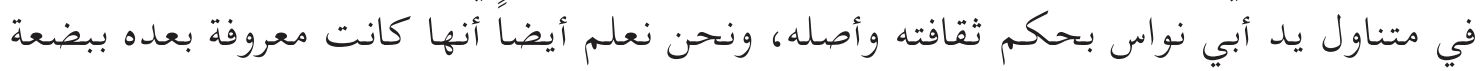

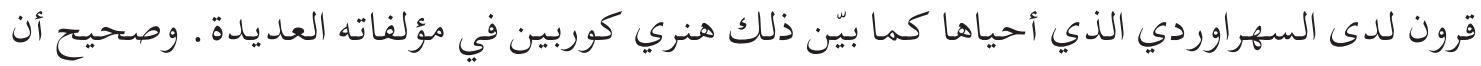

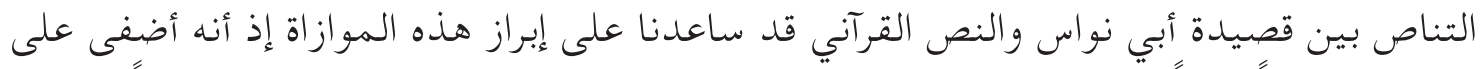

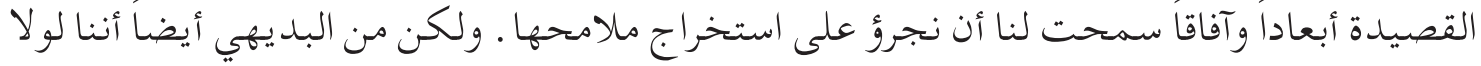

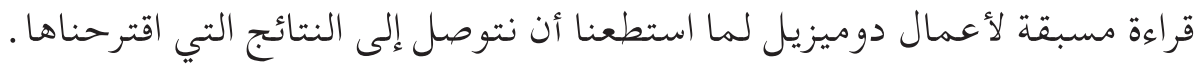

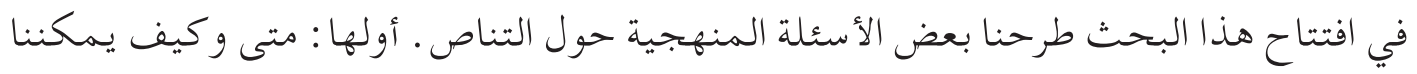

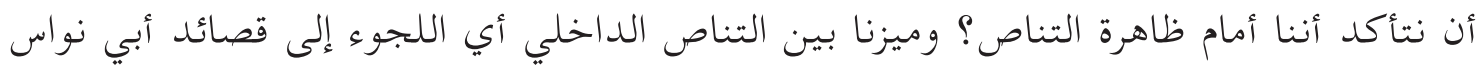

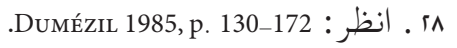

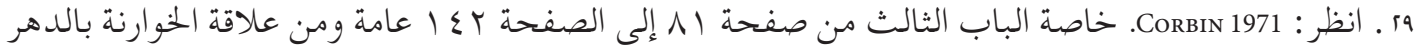

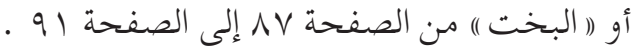




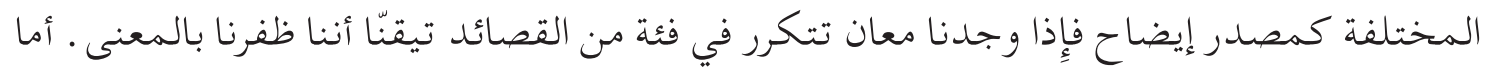

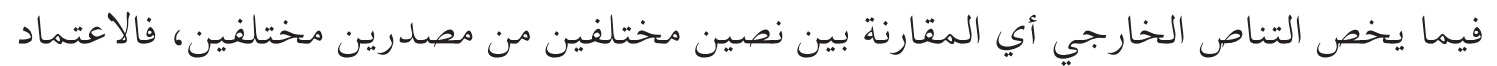

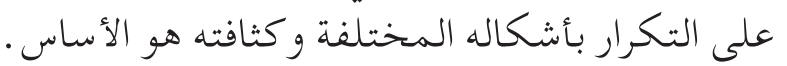

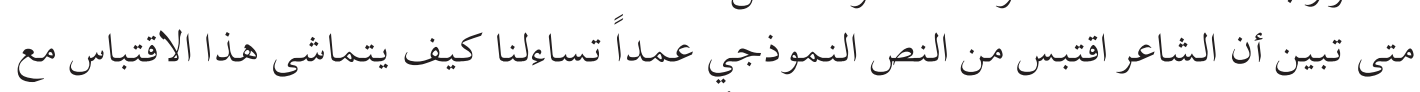

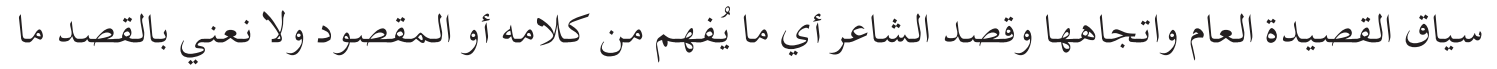

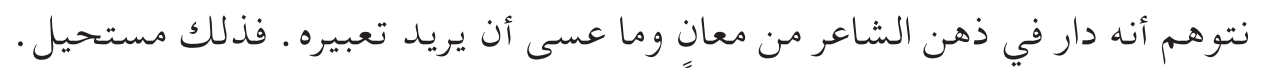

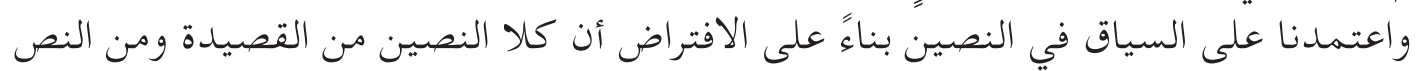

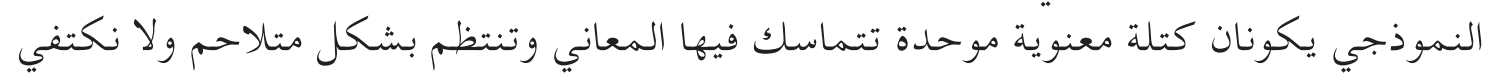

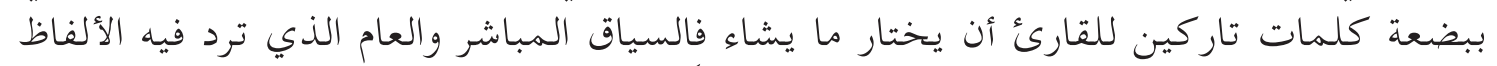

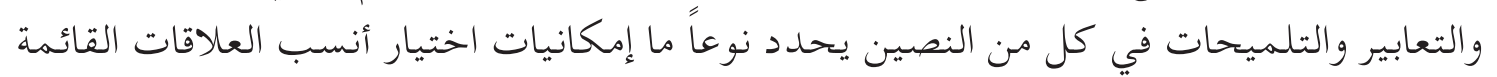

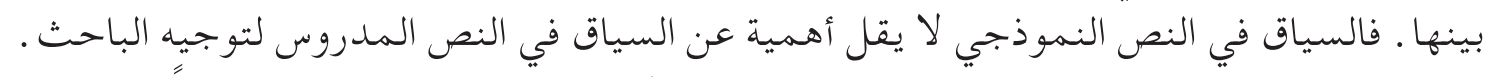

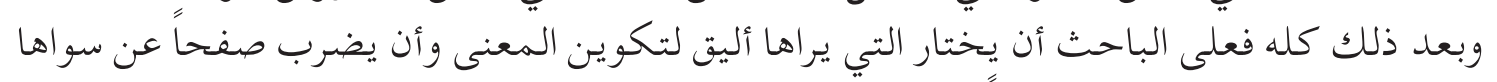

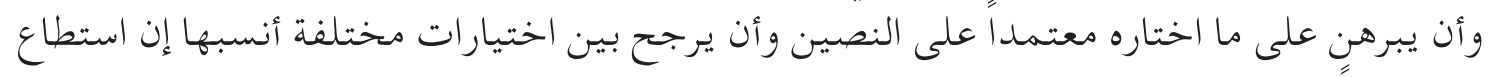
إليه سبيلا.

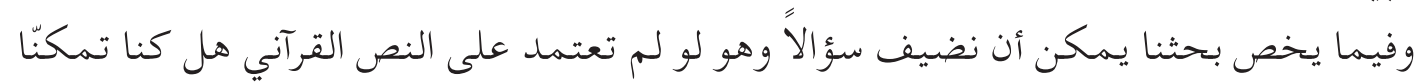

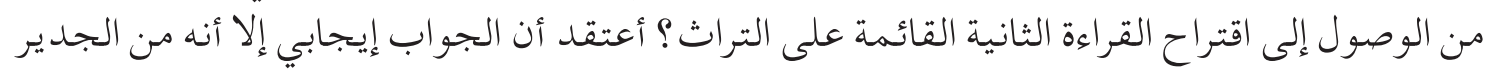

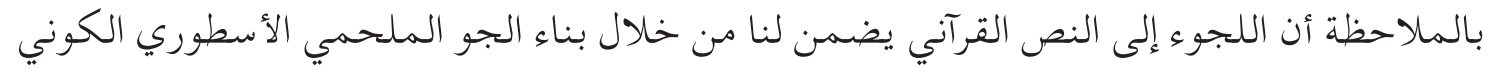
المزيد من التيقن من صحة القراءة الثانية .

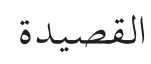

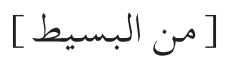

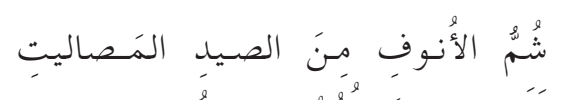

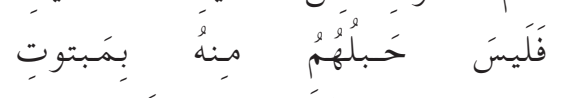

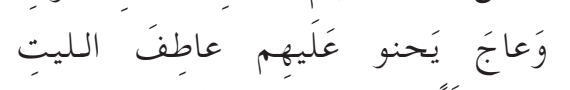

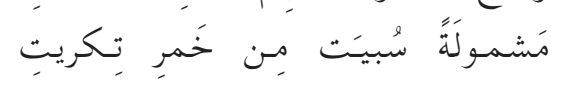

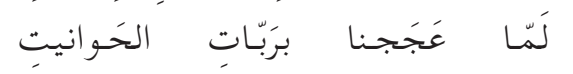

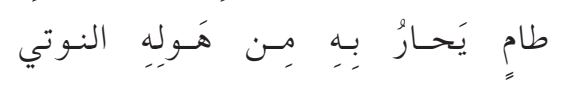

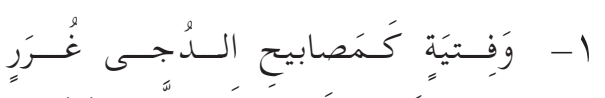

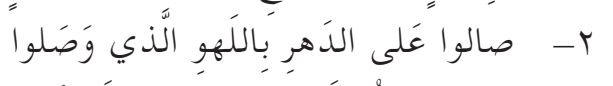

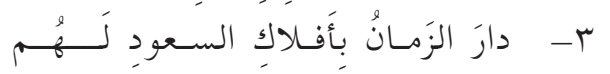

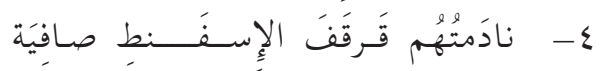

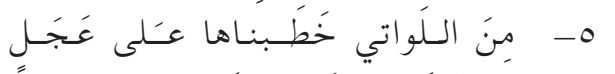

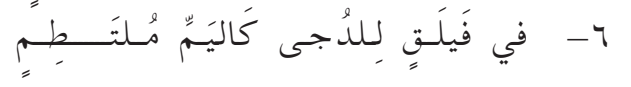




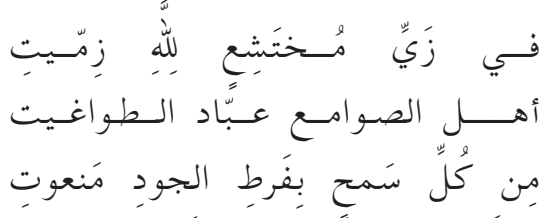

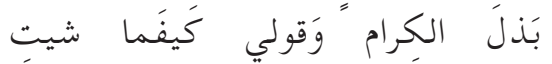

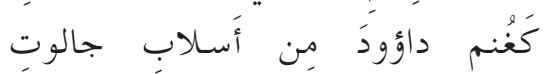

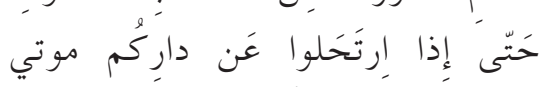

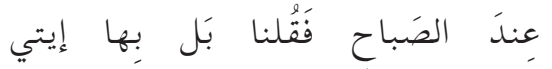

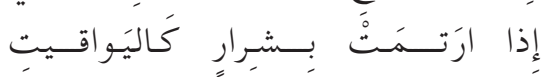

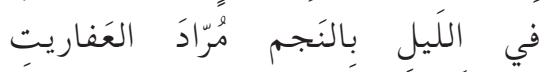

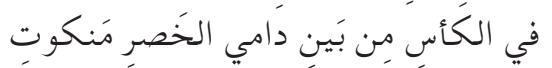

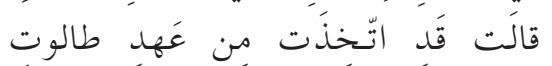

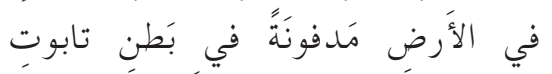

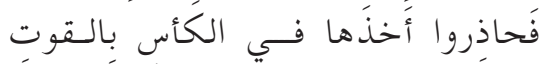

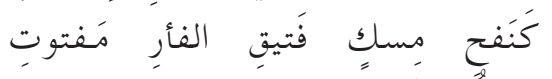

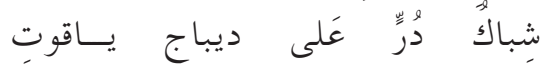

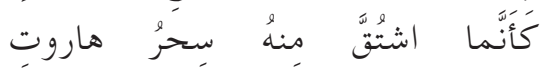

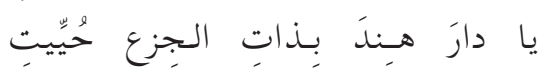

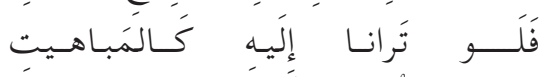

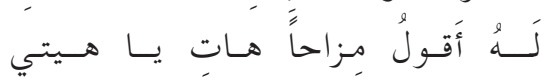

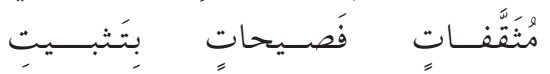

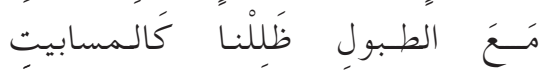

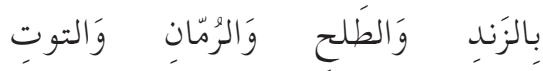

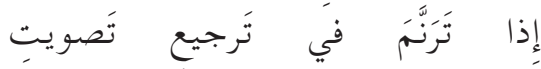

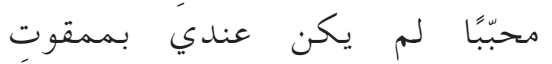

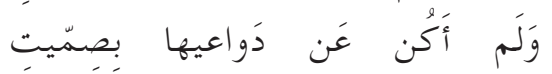

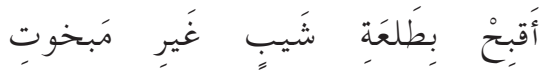

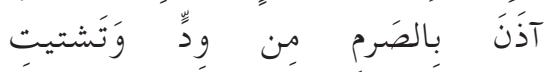

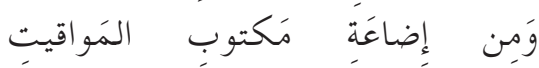

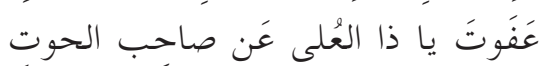

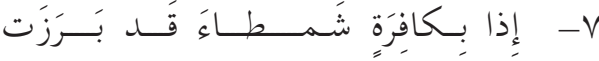

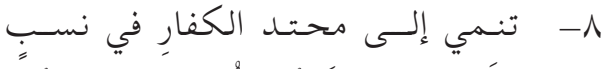

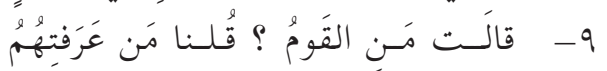

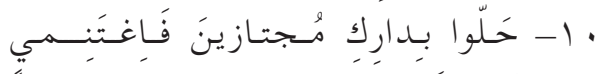

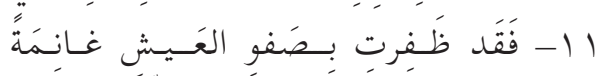

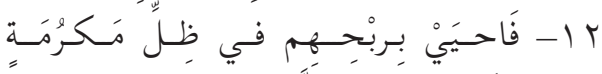

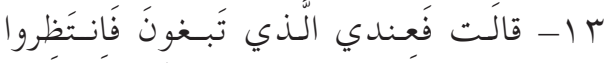

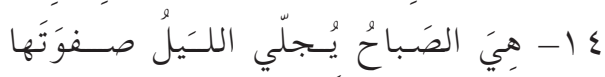

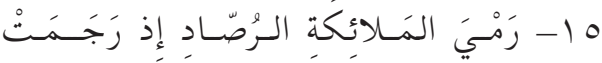

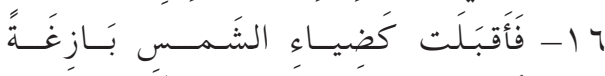

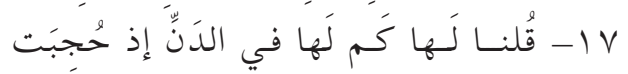

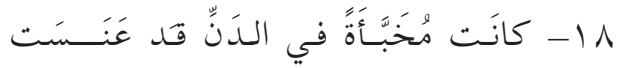

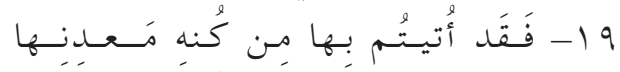

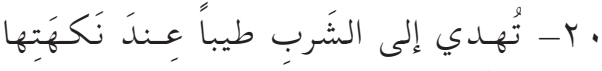

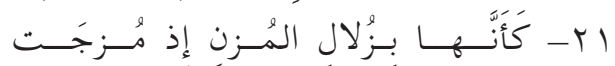

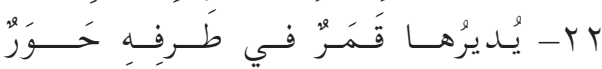

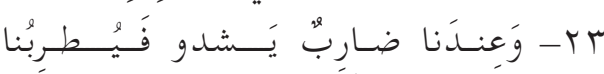

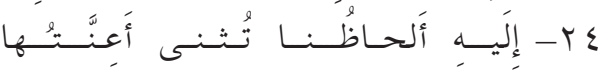

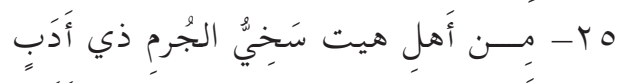

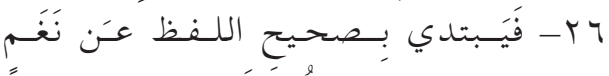

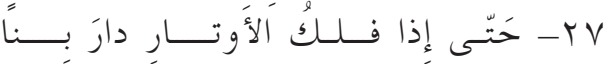

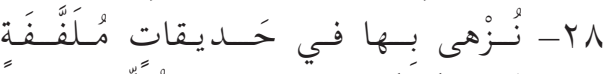

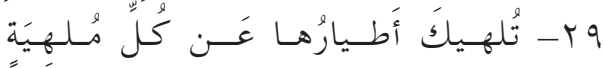

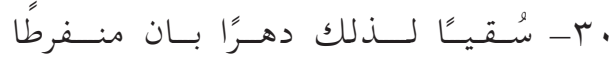

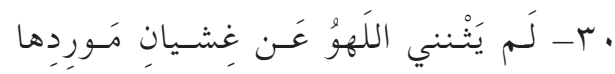

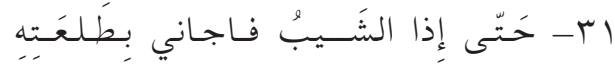

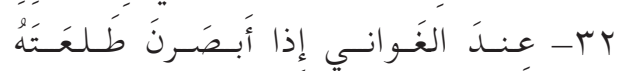

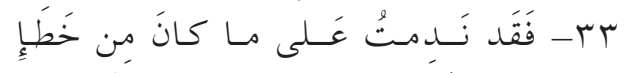

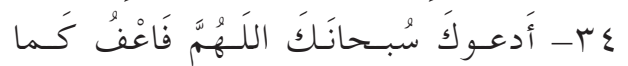




\section{جدول الاقتباسات}

\begin{tabular}{|c|c|c|c|}
\hline & القصيدة & النص القرآني & \\
\hline / باV.1 & وفتية كمصابيح الدجا غُرَرٍ & 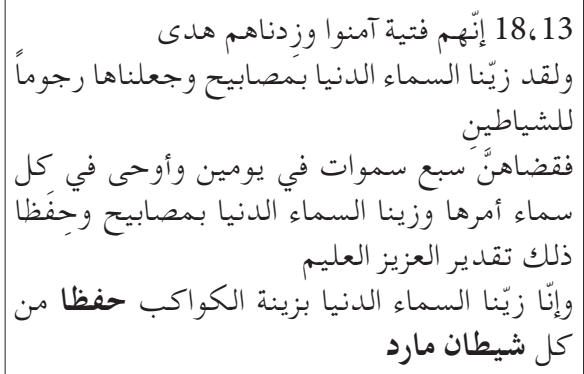 & 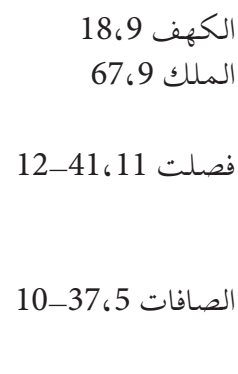 \\
\hline |2بv.2 & صالو اعلى الدهر باللهو الذي وصلوا & وقالوا ... وما يُهْلكنا إلا الدهرُ & 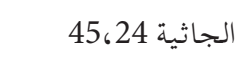 \\
\hline $\begin{array}{r}\text { |3بv.3 } \\
\text { | } 27 \varphi \text { V. } 27 \\
\end{array}$ & 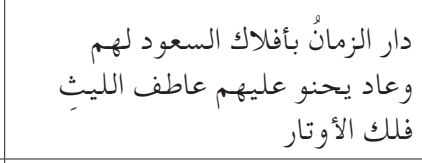 & 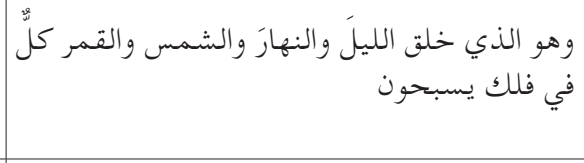 & الأنبياء 33، \\
\hline / 8بv. 8 & أهل الصوامع عُبّاد الطواغيت & وبيع ل. دوفع الله الناس بعضهم ببعض لهدمت صوامع & الحج 40،22 \\
\hline | 11بv.11 & 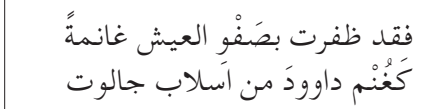 & & البقرة 25-249،2 \\
\hline | 12بV. 12 & 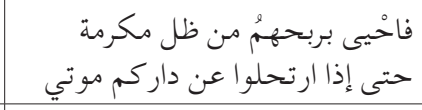 & & \\
\hline | 15بv. 15 & 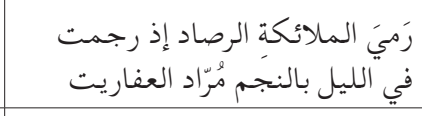 & شيطان مارد ... إيّا الدماء الديا بزينة الكواكب حفظاً من كل & الصافات 37، \\
\hline | 16بV. 16 & فأقبلت كضياء الشمس بازغةً & 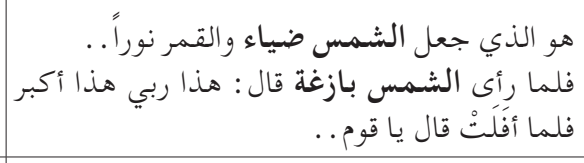 & 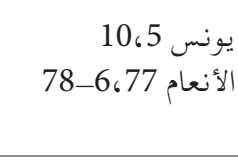 \\
\hline | 17بV. 17 & قالت قد اتخذتْ من عهد طالوت & 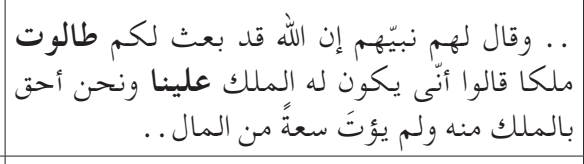 & البقرة II , 247 \\
\hline | 18بV. 18 & 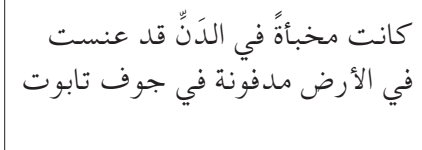 & 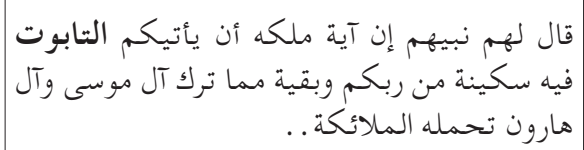 & البقرة II , \\
\hline | 20بV.20 & 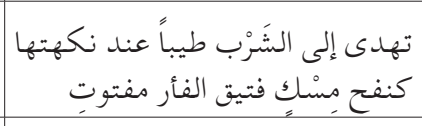 & يسقَون من رحيقٍ مختوم ختامه مسكُ & $26-23 ، 25$ \\
\hline $\begin{array}{l}\text { / } 21 ب V .21 \\
\text { /22بV.22 } \\
\text { /23بV.23 }\end{array}$ & 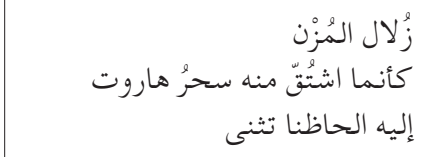 & . . وما أنزل على الملكين ببابل هاروت وماروت & البقرة 102 II \\
\hline
\end{tabular}




\section{RÉFÉRENCES}

Audebert, Claude, 1998: «Dans les outres anciennes versons un vin nouveau », in Dichy, J. et Hamzé, H. (éds.), Le voyage et la langue : mélanges en l'honneur d'Anouar Louca et d'André Roman, Damas, Presses de l'Ifpo, p. 87-104.

AudeBert, Claude, 2000 : « Emprunts faits au Coran par quelques poètes $\mathrm{du} \mathrm{II}^{\mathrm{e}} / \mathrm{VIII}^{\mathrm{e}}$ siècle », Arabica 47, p. 457-477.

CAHen, Claude, 1965 : « Futuwwa », Encyclopédie de l'Islam, 2 ${ }^{\mathrm{ème}}$ éd., Leyde, Brill, vol. 2, p. 983-987.

Corbin, Henry, 1971 : En islam iranien. Aspects spirituels et philosophiques, vol. 2 : Suhrawardî et les platoniciens de Perse, Paris, Gallimard, 1971.

Dumézil, Georges, 1945 : Jupiter, Mars, Quirinus, vol. 3 : Naissance d'Archanges. Essai sur la formation de la religion zoroastrienne, Paris, Gallimard.

DumÉzIL, Georges, 1981 : Mythe et Epopée, Paris, Gallimard, 4 ème éd., 3 vol.

DumézIL, Georges, 1985 : Heur et Malheur du Guerrier. Aspects de la fonction guerrière chez les Indo-Européens, Paris, Flammarion, 1985.

EnDERwitz, Suzanne, 1989 : « Du fatā au zarîf, ou comment on se distingue ? », Arabica 36, p. 125-142.

FAHD, Toufic, 2002 : « Țāghut », Encyclopédie de l'Islam, $2^{2 ̀ m e}$ éd., Leyde, Brill, vol. 10, p. 101-102.

GRANDI, Ida Zilio, 2006 : « Jonas, un prophète biblique dans l'islam », Revue de l'histoire des religions 223/3, p. 283-318.

Montgomery, James E., 1994 : «Revelry and Remorse : a Poem of Abū Nuwās », Journal of Arabic Literature 25, p. 116-134.

PuECH, Henri-Charles, 1947 : «De la mythologie indo-iranienne à la légende juive des anges Azael et Šemhazai ou Harūt et Marūt », Revue de l'histoire des religions 133, p. 221-225.

ZaKHARIA, Katia, 1987 : « Les références coraniques dans les Maqāmāt d'al-Ḥarīrī : éléments d'une lecture sémiologique », Arabica 34, p. 275-286.

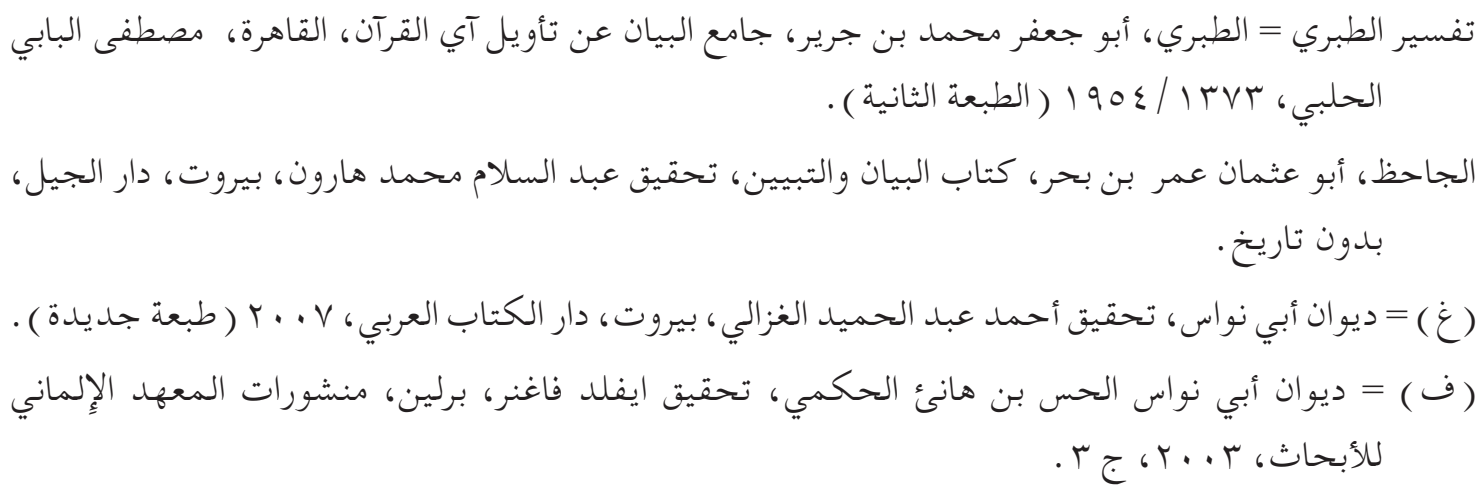

.Le Coran, trad. R. Blachère, Paris, G. P. Maisonneuve, 1949-1950, 2 vol. 
